\title{
Measuring skill shortages
}

Citation for published version (APA):

Borghans, L., de Grip, A., \& van Smoorenburg, M. S. M. (1998). Measuring skill shortages.

Researchcentrum voor Onderwijs en Arbeidsmarkt, Faculteit der Economische Wetenschappen. ROA Reports No. 4E https://doi.org/10.26481/umarep.199804E

Document status and date:

Published: 01/01/1998

DOI:

10.26481/umarep.199804E

Document Version:

Publisher's PDF, also known as Version of record

\section{Please check the document version of this publication:}

- A submitted manuscript is the version of the article upon submission and before peer-review. There can be important differences between the submitted version and the official published version of record.

People interested in the research are advised to contact the author for the final version of the publication, or visit the DOI to the publisher's website.

- The final author version and the galley proof are versions of the publication after peer review.

- The final published version features the final layout of the paper including the volume, issue and page numbers.

Link to publication

\footnotetext{
General rights rights.

- You may freely distribute the URL identifying the publication in the public portal. please follow below link for the End User Agreement:

www.umlib.nl/taverne-license

Take down policy

If you believe that this document breaches copyright please contact us at:

repository@maastrichtuniversity.nl

providing details and we will investigate your claim.
}

Copyright and moral rights for the publications made accessible in the public portal are retained by the authors and/or other copyright owners and it is a condition of accessing publications that users recognise and abide by the legal requirements associated with these

- Users may download and print one copy of any publication from the public portal for the purpose of private study or research.

- You may not further distribute the material or use it for any profit-making activity or commercial gain

If the publication is distributed under the terms of Article $25 \mathrm{fa}$ of the Dutch Copyright Act, indicated by the "Taverne" license above, 


\section{Measuring Skills Shortages}

ROA-R-1998/4E

Lex Borghans

Andries de Grip

Michel van Smoorenburg

Research Centre for Education and the Labour Market

Faculty of Economics and Business Administration

Maastricht University

Maastricht, January 1998 
ISBN 90-5321-229-9

SEC98018/LB 


\section{Contents}

Page

Acknowledgement

Summary

1 Introduction 1

2 Definition of skills shortages 5

2.1 Introduction 5

2.2 Skills as an investment in human capital 5

$\begin{array}{ll}2.3 \text { Consequences of skills shortages } & 10\end{array}$

$\begin{array}{ll}2.4 \text { The level of aggregation } & 13\end{array}$

$\begin{array}{ll}2.5 \text { Summary: proposal for a set of indicators } & 13\end{array}$

3 The observation of skills shortages 17

$\begin{array}{ll}3.1 \text { Introduction } & 17\end{array}$

3.2 The measurement of skills shortages based on the perception of $\begin{array}{ll}\text { employers } & 18\end{array}$

3.3 The measurement of skills shortages based on observed behaviour 20

$\begin{array}{ll}3.4 \text { Conclusion } & 23\end{array}$

4 The interpretation of different indicators 25

4.1 Overview of various measures used 25

4.2 Preferred instruments for measurement 41

5 Outline for a research programme 45

$\begin{array}{ll}5.1 \text { Introduction } & 45\end{array}$

5.2 Skills shortages and economic development, employment
and unemployment

5.3 Outline of the research programme 51

$\begin{array}{ll}\text { References } & 57\end{array}$ 



\section{Acknowledgement}

Study for the European Commission, DG XXII, under contract no. 96-00-A26-000700, in the framework of the fifth general objective of the white paper Education and Leaming, Towards the Learning Society. This fifth objective is to 'treat capital investment and investment in training on an equal basis'. The authors like to thank Rolf van der Velden for his fruitful comments. 


\section{Summary}

Education and training are generally regarded as major factors in competitiveness and economic development. The White Paper on Teaching and Learning: Towards the Learning Society of the European Commission (1996) suggests as a guideline for action to 'treat material investment and investment in training on an equal basis'. For that reason information is needed about education and training that may support investment decisions regarding this human capital.

This aim of this report is:

1. to define a set of adequate indicators of skills shortages that stresses the economic restraints that result from the lack of certain skills, and

2. the provision of an outline for a research programme to be launched with regard to the effects of skills shortages on economic development, employment and unemployment.

In chapter 2 a skills shortage is defined as the difference between the skills actually available and the skills that would have been available if all persons had developed their skills optimally by education, training and experience.

Two aspects of this definition are important. Firstly, a consequence of this definition is that it is not the formal qualifications that determine the skills available, but these skills depend on what has actually been learnt in education and training, while furthermore an adequate organisation of the work might induce new skills by the experience that results from it. As a consequence, not only the amount of time or money spent on education, training and experience, but mainly the way in which these efforts are applied determine the adequacy of the learning investments.

Secondly, the focus of the definition of skills shortages on optimal economic development, broadens the concept of skills shortages compared to the classical skills shortage. In its narrow definition skills shortages are defined as 'open vacancies' in which the demand for certain skills exceeds the supply. In practice, wage competition and adjustment behaviour of firms will diminish these open skills shortages without actually solving the economic consequences of the shortages. Wage competition will regulate the allocation of scarce skills but has no direct effect upon the supply of these skills, since education and training take time. Other adjustment policies, such as retraining of people with partially inadequate skills will lead to higher costs than necessary if adequate learning investments had been made in time. In section 2.2, six examples are provided of different forms in which skills shortages may manifest themselves.

A set of indicators has therefore been developed, which is necessary to grasp not only the classical 'open' skills shortages, but also high-wage or masked skills shortages. This set contains the following indicators:

1. the quantitative shortage of skills 
2. the quality of these skills

3. the costs at which these skills can be employed

4. the question whether employers perceive the shortages

5. the adjustment measures that employers take to reduce the costs of skills shortages

Chapter 3 and 4 are devoted to the possibilities of measuring these five indicators and the problems that are to be expected for this measurement. Chapter 5 sketches the way in which the concept of skills shortages introduced in this report may be used to investigate the extent of skills shortages in the EU and its effects on economic development, employment and unemployment. We suggest a research programme that consists of three parts.

Part A is a Skills Shortages Monitor that provides an overview of the skills shortages in the EU. The Monitor will be based on the five indicators proposed. The collection of existing data within this consistent framework of skills shortages will largely improve the knowledge about the extent of skills shortages in various countries, regions, skill groups, occupations and industries. Of course the existing data will not provide all information that is required from a theoretical point of view, but experience has shown that the combination of different data sources will certainly improve our insight in skills shortages in its different manifestations considerably. Furthermore, the experience of such an investigation will provide a clear understanding of essential data that are still missing. Compared to a research programme that collects entirely new data, based on a consistent and complete framework, this approach reduces costs, avoids a long time lag before information becomes available, and will lead to a much more adequate information system on skills shortages due to the learning process involved. The construction of indicators on skills shortages on the basis of existing data generates the experience thay may be used to supplement existing data with targeted additional surveys. The additional surveys will be less expensive and at the same time better suited for their job.

Although the Skills shortages Monitor will provide a very useful instrument for policies on education and training itself, the analyses of the consequences of skills shortages on economic development, employment and unemployment require two additional parts in the research programme. For part $B$ we suggest an analysis of the relationship between skills shortages and productivity. For each country, it can be estimated how great lost production as a result of skills shortages is, and what types of skill form the major bottleneck in the production process. As a consequence, this productivity analysis provides insight in the seriousness of the skills shortages concerned. Of course, the data set on skills shortages developed in part A, will constitute the basis for these analyses. Production function models such as in Cörvers (1997) seem to be the most appropriate framework for this. In the same way, in part $\mathrm{C}$ of the research programme, the relationship between skills shortages and employment and unemployment can be analysed. Hereby a distincion should be made between the four different effects human capital could have on the production 
process: the worker effect, the allocative effect, the research effect and the diffusion effect. 


\section{Introduction}

Education and training are generally regarded as major factors in competitiveness and economic development. Their important role in the production process is reflected in the term human capital, indicating that in addition to physical equipment, an adequately educated labour force is crucial for economic success. Wood (1995) adds to this that due to the fact that physical capital is becoming more and more mobile, human capital will become the decisive factor in international competitiveness. Following the human capital concept, the White Paper on Education and Learning: Towards the Learning Society of the European Commission (1996) suggests as the fifth guideline for action to 'treat material investment and investment in training on an equal basis'. For that reason education and training should not only get a priority with regard to European competitiveness, but this also presupposes a change of approach in which expenditures for education and training are regarded as investments rather than as spendings.

In order to support investment decisions in human capital, adequate information is needed. In line with the White Paper, OECD (1996a) stresses the importance of human capital accounting for the knowledge economy. This information should in the first place point at skills for which shortages occur or are expected to occur. These skills shortages point at fields of education or training that might require additional investments. For this purpose Oosterhuis and Van der Velden (1994) have proposed the development of a Skills Barometer, measuring both quantitative and qualitative skills shortages. In the second place information is needed about the effect these skills shortages have on economic development, employment and unemployment, to give insight in the expected gains of investments in human capital, as it is frequently stated that despite the high unemployment significant skills shortages prevent higher employment growth in Europe and the achievement of a lower level of unemployment.

In line with the point of view in which education is regarded as an investment, this report focuses on two research objectives:

- the definition of a set of adequate indicators of skills shortages that stresses the economic restraints that result from the lack of certain skills;

- the provision of an outline for a research programme to be launched with regard to the effects of skills shortages on economic development, employment and unemployment.

The first step to be taken in this study is to investigate the concept of skills shortages. The term skills shortages, however, is a rather vague one and is interpreted in different ways by different authors. For that reason, Chapter 2 will sketch a theoretical framework in which the various definitions of skills shortages can be placed. In this theoretical framework the question whether the skills shortages lead to lost production is taken as a point of departure. Consequently, these skills shortages may differ from the skills shortages perceived by employers. 
For example, 'hidden' forms of skills shortages, in which e.g. employers do not realise the existence of lost production, are also included. Furthermore, skills shortages may be the result of both underinvestment and inadequate investments in (certain forms of) education, on-the-job training and experience. The definition used also enables us to analyze the possible effect of skills shortages on economic development, employment and unemployment. The explication of the theoretical framework improves the internal consistency or construct validity of the measurement and leads to a typology of the various concepts and measures of skills shortages.

The theoretical framework will focus on two important aspects of skills shortages: the point of reference and the effects of skills shortages. It will be shown that differences between degrees of skills shortages can be explained by these two aspects. Firstly, conceptual differences may arise from different views on the point of reference for what is considered as a skills shortage. For example, Bosworth and Warren (1992) state that skills shortages occur when supply and demand for a certain skill diverge, and continue as long as price adjustments fail to overcome the discrepancies between supply and demand of particular skills. Implicitly, they therefore state that their point of reference is a situation in which supply and demand are balanced as a result of market wages. Such market forces, however, do nothing to diminish the skills shortage. Wage adjustments only redistribute the small quantity of skills available, but do not directly generate more skills. Economic problems that continue to exist even if wages are flexible, are therefore neglected in a definition of skills shortages as perceived by employers. Secondly, skills shortages will probably induce employers to change their behaviour. Depending on the type of skill concerned and the circumstances in which employers have to operate, employers have several alternatives, such as recruiting personnel with different qualifications, increasing internal training activities, leaving a vacancy open, et cetera. Again, although adequate adjustment policies may hide skills shortages, there will still be lost production compared with a situation of optimal educational investments. The measurement of skills shortages requires that all these possible consequences are recognised as indicators of skills shortages. Investigation of the different aspects of skills shortages leads to a proposed set of indicators that incorporates all relevant aspects for the monitoring of skills shortages.

Chapter 2 defines the proposed indicators within the theoretical concept. To operationalise the measurement of skills shortages, the set of indicators must be implemented in practical instruments of measurement. Chapter 3 and 4 are devoted to this implementation. Chapter 3 describes the various ways skills shortages can be observed. On the basis of the theoretical framework of Chapter 2, we will discuss how skills shortages can be observed empirically by (1) registration of employers' search activities, (2) surveys among employers, (3) monitoring adjustment behaviour, (4) comparisons between countries, sectors and occupations, and comparisons in time, and (5) econometric analyses of the functioning of the labour market. For these different kinds of measurement, we analyse which points of reference are implicitly assumed in a certain indicator and what assumptions are 
made about the effects of skills shortages on the behaviour of employers and employees. Possible errors and biases in the measurement are also discussed.

Chapter 4 presents different indicators of skills shortages that are used in economic and sociological literature. Concrete measures of skills shortages, as used in practice, will be classified systematically. On the basis of their definition and experience with their use, these indicators will be placed within the theoretical framework of Chapter 2 and the investigation of methods for implementation in Chapter 3. We will systematically determine the aspect of skills shortages which each of the indicators covers, as well as the validity of the indicators at this point. Conclusions will be drawn about the preferred operationalisation of the proposed set of indicators of skills shortages.

The availability of skills is generally seen as an important factor in the competitiveness of countries. Chapter 5 therefore sketches a framework for the links between the different forms of skills shortages and their possible effects on economic development, employment and unemployment. The way in which skills shortages have been defined in terms of lost production, implies that we may also expect a close link between skills shortages and these economic developments. In this chapter, we will discuss the relationship between the skills shortages concept as defined in Chapter 2 and operationalised in Chapter 4, and possible obstructions of economic developments in the various EU Member States. This framework forms an outline for a research programme that aims at making an empirical study of the effect of skills shortages in the European Union. On the basis of the set of indicators developed in the present report, this research program will investigate the effects of skills shortages on economic development, employment and unemployment. 


\section{Definition of skills shortages}

\subsection{Introduction}

In this chapter, we will sketch a theoretical framework for skills shortages. This framework makes it possible to develop a typology of the various measurements of skills shortages and to evaluate the different measures for their construct validity, i.e. to what extent does the theoretical construct measured fit into a broader theoretical framework? On the basis of lost production, a definition is introduced that links skills shortages with underinvestment in education. These shortages may be both of a quantitative and a qualitative nature and possibly differ from the shortages perceived by employers. It will be shown that, depending on the causes of skills shortages and on the reaction of employers to such shortages, these skills shortages may manifest themselves in different ways. Firstly, it will be shown that wage competition between employers as a reaction to skills shortages may reduce perceived skills shortages, but will not diminish the major economic consequences of skills shortages, i.e. the resulting lost production. Secondly, we will discuss the consequences for skills shortages of employers using, probably costly, alternatives as an adjustment to skills shortages. These adjustments can be regarded as curative policies. Thirdly, attention is paid to prevention of skills shortages. Lastly, we will show what consequences a shift in the level of aggregation will have for the measurement of skills shortages.

The chapter ends with a diagram which summarises the theoretical framework. This diagram is a proposal for a set of indicators that seems to be adequate for the monitoring of skills shortages.

\subsection{Skills as an investment in human capital}

Skills can be defined as abilities to perform certain productive tasks. This means on the one hand that a skill is associated with a certain task or job, and on the other hand that people who do not possess this skill will not be able to perform this task or will be less productive in this task compared to those who do possess the skill concerned. Skills can affect productivity in different ways. In Chapter 5, we will investigate the relationship between different aspects of skills - the worker effect, the allocative effect, the diffusion effect and the research effect - and productivity. Skills can be acquired in three different ways:

1. people differ in their natural abilities;

2. education and training will improve the skills people have;

3. experience may increase skills.

The acquisition of skills is therefore partly determined by factors which are not under our control but also by factors that can be influenced by choices regarding education, training and experience. In economic literature, skills are usually indicated by the term human capital. Continuing this analogy with physical capital, 
the natural talents of people can be regarded as natural resources, whereas learning is equivalent to an investment in human capital. Experience can be regarded as a by-product of production - in the case in which productivity is the first priority - but also as a form of training - in the case in which the tasks which have to be done are chosen to increase experience for its own sake, as is the case in apprenticeship training. The first case can be classified as 'learning by doing' while the second case is classified as informal learning or 'on-the-job training' (see Killingsworth, 1982). Skills shortages can therefore also be the result both of underinvestment in education and in training, and of experience on the job.

For the analyses of skills shortages, it is important to distinguish between natural resources and investments in human capital. As will be discussed later, skills shortages is a relative concept. A shortage indicates a deficiency compared to a certain ideal situation. However, there seems to be little point in discussing shortages of natural resources, since there is (except for migration) no way in which these resources can be increased. The analyses of skills shortages will therefore be based on the question whether more or different investments in human capital would have been desirable given the demand for skills in companies.

\section{Definition of skills shortages}

Speaking of skills shortages implies that there are fewer skills available than could be regarded as normal. As skills shortages are a relative concept, a consistent use of the concept of skills shortages requires this point of reference to be defined. If we regard investment in skills as human capital, it seems evident that we should take a situation in which all persons have optimally developed their skills as a point of reference. This means that everyone's investments in skills are developed to such an extent by education and experience that additional investments are no longer cost-effective. Optimal investment in skills is therefore restricted by the cost of training, but also by the capabilities and preferences of the persons involved. This optimality refers to the macro level, which means that such investments should contribute to the economic development of the country. Skills shortages therefore lead directly to lost production, compared to a situation of optimal investments in skills. The definition of skills shortages is therefore:

A skills shortage is the difference between the skills actually available and the skills that would have been available if all persons had developed their skills optimally - from a macro point of view - by education, training and experience.

With respect to this definition of skills shortages, two remarks must be made.

Firstly, a skills shortage refers to a mismatch situation in which there has been an underinvestment in human capital for a particular skill. On the other hand, overinvestment is also possible. People may invest in education and experience to such an extent that the benefits no longer cover the costs. The investment may be too large per se, but it is more likely that investments are made in the 'wrong' skills. 
This means that people invest in skills that do not contribute enough to production to recover the costs, while greater investments in different skills would have been useful. This may mean that people choose less valuable learning programmes, but also that the quality of a learning programme is low in the sense that it focuses too much on the acquisition of skills that are not important (or not important anymore) for a good labour market performance. Skills shortages and overinvestment may therefore occur at the same time. Improvements of investment in human capital are therefore not only a matter of increasing gross investments in education and training, but may also be obtained by an improved allocation of such investments.

Secondly, skills have been defined as abilities to perform certain productive tasks. The central element in the concept of skills is therefore the actual ability people have, rather than their formal educational status as indicated by their diplomas. Although the point of reference is the optimal amount of skills that could have been acquired, this does not mean that formal education is the only means by which such skills can be obtained. As mentioned above, on-the-job training, informal learning and experience ('learning by doing') may also increase the skills of workers, while on the other hand people may acquire formal diplomas without adequate abilities for the job concerned. Although for measurement purposes it will often be necessary to use classifications of education, it is important to bear in mind that discrepancies will exist between the expected and actual skills of people within a certain formal educational category. An indicator for skills shortages should therefore also take these discrepancies into account.

\section{Examples}

Skills shortages as defined above may take very different forms. To illustrate these different kinds of manifestations, we provide six examples in which past decisions concerning skills acquisition turn out not to be optimal.

1. There are not enough plumbers for all the installation work to be done. This means that it would have been beneficial for society if this quantitative shortage had been anticipated and more people had acquired such skills.

2. Older civil servants do not have sufficient managerial experience. The work of younger civil servants is focused too much on direct production, while reallocation of tasks would have generated additional managerial skills that are very valuable later in one's career.

3. Employers do not realise the value of craftsmanship at the intermediate level. Findings like this are frequently obtained by comparative research of the British National Institute for Economic and Social Research (see Steedman and Wagner, 1987, and Ryan, 1991). It also implies that if employers recruited more people with such skills, and hence put a greater value on these skills more, productivity would be improved. If undervaluation of these skills leads to lower participation in education and training for these skills, the result will be skills 
shortages. Employers do, however, not notice this skills shortage themselves.

4. Ophthalmologists earn very high incomes. Due to restricted enrolment in these courses, ophthalmologists are scarce and their fees are high. As a consequence, people who would normally have used the services of these doctors, go to an optician instead, leaving the ophthalmologists only the more complicated cases. Matching the need for these specific tasks with the supply of ophthalmologists will not indicate at a shortage, however.

5. Electrical engineers have sufficient skills for design, but commercial skills are becoming more and more important. This suggests a qualitative skills shortage. Although the level at which these electrical engineers perform design tasks may be sufficient, changes in the character of the job may require different skills. Investment in these skills at school or by experience or training during their working career would have improved the employability of such workers.

6. Expensive retraining of graduates to acquire computer skills is needed. The scarcity of computer scientists makes computer firms invest in training programs for graduates from other disciplines. This implies relative expensive educational routes. Although double qualifications will certainly provide additional value, anticipation of such shortages could have saved costs. Such retraining therefore indicates skills shortages.

The examples show that skills shortages can take very different forms. Furthermore, the investments in learning that were not made, may refer to education, but also to training during professional careers and the acquisition of certain experience by an appropriate organisation of the work. Skills shortages may occur due to the absence of certain investments in learning, but also due to a low quality of education and training, the emphasis not being on the aspects that are the most relevant ones for the work, or investments in skills that are not the most relevant for the labour market.

\section{Reasons for skills shortages}

As a consequence of the definition, a skills shortage implies a situation in which at a given moment in time it appears that certain investments in skills would have been appropriate in the sense that the benefits of an additional unit of these skills exceed the costs of investment. The observation of skills shortages therefore naturally leads to the question why this investment was not made.

The reasons for such underinvestment may refer both to the supply and the demand side of the labour market. On the supply side, individuals may underinvest in education because:

1. There are institutional obstructions for such investments. In formal education, there may be a numerus clausus, restricting the number of students. On-the-job training may be hindered by a 'prisoner's dilemma' in which employers are not 
prepared to invest in training for certain skills if competing firms may profit from these investments, whereas learning by doing could be obstructed by the need for direct productivity, which may stand in the way of the allocation of labour to tasks which stimulate the formation of experience.

2. Misperception of the costs and benefits of investments in certain skills. The costs include not only the pecuniary costs, but also depend on the capabilities and preferences of individuals. People may think that they are not capable of obtaining certain skills, or may have a false perception of the satisfaction certain jobs provide. A misperception concerning the benefits of skills may arise if students and workers have an incorrect view of the value of specific skills for employers. This is where the dynamics of the labour market becomes important. Making adequate learning investments requires anticipation of the future needs for certain skills to avoid irrelevance or outdatedness. Both qualitative and quantitative aspects of work will change. Technological progress plays an important role, but organisational changes also lead to changes in job requirements. Kunst et al. (1996) have shown that the introduction of total quality management and ISO certification is a major reason for training in firms. To avoid skills shortages, future skills requirements must be anticipated.

3. There may be a discrepancy between the individual versus the social balance of costs and benefits of investing in particular skills. These discrepancies may be caused by unattractive employment conditions, such as low wages, unfavourable working conditions or bad career prospects.

On the demand side, skills shortages can also be caused by obstructions, misperceptions and discrepancies in the balance of costs and benefits:

1. Obstructions to the recruitment of personnel with certain skills may be introduced by legal restrictions that prescribe certain formal qualifications for particular jobs, while individuals lacking such formal educational qualification, but who do have relevant experience could be a good (and less expensive) alternative.

2. Misperceptions occur if employers have an incorrect idea of the value of certain skills for their production processes. Again, this means that the dynamics of the labour market is important. To avoid skills shortages, employers must anticipate future skills requirements. Early anticipation makes it possible for them to promote adaptation of their employees to new developments at an early stage.

3. Discrepancies between the balance of costs and benefits for employers versus society may be caused by the high additional costs that employers have to pay for certain skills. If for example investments by firms in training are not taxdeductible, while the profits that arise from these investments are taxed the firm experiences relatively higher costs than society. 


\subsection{Consequences of skills shortages}

All possible causes of skills shortages lead to a situation in which fewer people have certain skills than would have been the result of optimal investment in education, onthe-job training and learning by doing. As a consequence, other skills (or people lacking certain skills) will be overrepresented compared to the optimal situation. The way in which such a skills shortage reveals itself and its economic consequences depend on the way employers react to these skills shortages. These reactions may depend on the cause of the shortage.

Since a skills shortage is a non-optimal economic situation, employers probably follow certain adjustment policies to reduce the costs of the shortage. If these adjustment policies are absent, an immediate discrepancy between the supply and demand of a certain skill will manifest itself. This is called a classical skills shortage. If employers are aware of the productivity possibilities of the skills concerned, they will perceive this discrepancy. The discrepancy can be formulated in quantities, or in qualities. Employers may perceive that for the specific skills, the required supply does not meet the demand, or that the quality of the skills they may obtain does not meet their needs. If employers are not aware of this productivity gap, because they underestimate the productivity potential of certain skills, de facto the same situation occurs, but indirect measurement is required because the perception of employers will fail to bring up such shortages.

For the measurement of skills shortages, it is important to take into account the possibility that employers react to this non-optimal situation. As will be shown below, such reactions may fundamentally change the observed situation, although the essence of the skills shortage, i.e. the lost production, remains unaffected. In a broad sense, there are two different ways in which employers may react. Firstly, they may start to compete on the market for the 'scarce good' - the skill for which there is a shortage - by increasing the wages for workers which have these skills, or by increasing their recruitment efforts. Such a competition does not reduce the shortage, but determines the distribution of the skill across the firms at the demand side of the labour market. Secondly, employers may take action to reduce the problems they face. Such adjustments do not fully compensate for the effects of skills shortages, but may diminish its negative effects. In the following subsection, attention is focused on the aspect of wage competition, while the next subsection will deal with adjustments to reduce the costs of skills shortages.

\section{Market reactions to skills shortages}

In the economic literature non-market wages are often assumed to be the cause of skills shortages (cf. Bosworth and Warren, 1992). Such a theory of skills shortages suggests that these shortages only exist until the moment when the market balances supply and demand by adjusting wages. Consequently, skills shortages only seem to be possible in cases where the market is not functioning well in the sense that wages do not clear the market. Sneessens (1995) provides an example of such 
research in which 'skill mismatch' is regarded as a situation in which wages do not adequately reflect the need for certain skills. Causes for such imbalances can be wage rigidity or high wages due to the market power of so-called insiders on the labour market. These analyses do, however, take the availability of skills for granted and therefore do not focus on the question that precedes the investigation of the allocation of skills, i.e. the question of the acquisition of skills and their adequacy for the labour market. Regardless of the adequate working of the wage mechanism, employment growth and economic development depend to a large extent on adequate investments in skills.

Restricting the view on skills shortages to wage adjustment processes neglects the major relevance of the skills shortages concept. Even if wages react to the scarcity of a certain skill, the scarcity itself, and therefore the lost production, does not disappear. It is therefore important to analyse what will happen when employers react to the situation of shortages they face.

Competition for scarce labour will indeed improve the allocation of skills across the firms which demand the skills. Rising wages in such a competing environment, or other policies that aim at the recruitment of scarce skills at the cost of other employers, such as an intensified search, will reduce the demand because the skills concerned will become too expensive for some employers. Jobs for which the productivity of a certain skill is relatively low will be the first for which demand is reduced when wages or other labour costs go up. Rising wages or costs therefore lead to a selection of the more productive jobs. This wage competition will however not increase the supply immediately. As mentioned above, the formation of skills can be regarded as an investment in human capital and as is the case with most investments, learning also takes time. In practice, this gestation period may take several years.

However, after the short-term wage adjustments, the measurement of skills shortages may suggest that the problem has disappeared. The skills shortages that an employer perceives become equal to zero: supply equals demand at the prevailing wage. But in this situation, skills shortages in terms of lost production still exist as supply is still below the optimal level. Comparing the actual skills shortages before and after short-term wage adjustment therefore leads to the picture that in both situations the quantitative or qualitative measures of skills are equal, but that before short-term wage adjustments the wage is equal to or lower than normal, while after wage adjustment the wage exceeds the normal wage. Compared to the optimal situation, the underinvestment in human capital is still present and therefore this situation must also be regarded as a skills shortage. This enables us to distinguish between a high-wage skills shortage and a classical skills shortage, as mentioned above. Contrary to classical skills shortages, in which supply is below the optimal level and the wage is equal to or lower than optimal level, high-wage skills shortages are characterised by supply below the optimal level but labour costs above the normal situation. 


\section{Adjustment mechanisms to reduce costs of skills shortages}

The wage competition process described above refers to the situation in which employers depend on a particular skill for their production process and have no possibilities to substitute this specific skill by related skills in the short term. The only way to meet their demands is therefore increased competition for the scarce skills. In practice, however, an employer has several alternative options to cope with skills shortages, such as:

1. recruiting personnel with different educational backgrounds, at higher costs or lower productivity

2. providing additional training to workers who lack the skills required but have a second-best educational background ${ }^{1}$

3. stimulating overtime of adequately skilled workers

4. substituting physical capital for human capital

5. stimulating interregional or international labour mobility

6. reducing the level of production

In general, these adjustments will be accompanied by costs compared to the normal situation in which there is no shortage for the skilled labour concerned and labour costs for this skill are not exceptional. If an employer faces recruitment problems, or if wage competition makes the skills concerned more expensive, such adjustments may become attractive alternatives. This implies that these substitution possibilities enable the employer to reduce the costs of skills shortages. The lower the costs of these substitution possibilities, the higher the potential reduction of the costs of skills shortages. It is important, however, to notice that again the presence of these adjustment mechanisms does not mean that skills shortages have been 'solved'. On the one hand the costs of skills shortages are reduced, since cost reduction forms the rationale for the adjustment strategy, but on the other hand adjustments lead to higher costs than in an optimal situation in which no skills shortages occur. Since adjustment policies may hide the existence of the shortages, we call this a masked skills shortage.

\section{Structural ways to avoid skills shortages}

So far, the analyses have focused on skills shortages and the adjustment processes to which these shortages could lead. These adjustment processes can be regarded as curative policies. Preventative policies are also possible, however. Factors that increase the risk of skills shortages can be influenced by structural characteristics which prevent skills shortages to some extent. An educational system, for example, in which a high degree of specialisation is reached, more easily leads to discrepancies between supply and demand than an educational system in which

1. Training of workers by firms will in general also be part of normal business. 'Additional training' therefore refers to a more than usual training effort. 
more general skills are taught. Borghans (1992) argues, however, that these general skills may lead to a more flexible supply but may at the same time decrease direct productivity. Similar to adjustments as a reaction to shortages, structural ways to avoid skills shortages may also have their costs. Another example of preventative action may be to monitor the labour market with respect to skills and provide forecasts which enable firms, individual workers, and policy makers to anticipate future skills shortages. This policy of making the relationship between education and the labour market more transparent will improve the investment decisions in human capital and therefore decrease future skills shortages (Borghans, 1993).

\subsection{The level of aggregation}

The study of the causes of and the reaction of firms to skills shortages provides insight in the consequences of skills shortages. This model, however, is only a partial model. In a way, such a partial analysis may mislead the interpretation of the situation. A partial model is based on the assumption that no changes occur on other markets. The model therefore analyses what happens if wage and quantity adjustments take place on the market concerned, while on other markets everything remains the same. This implies that the scope of the partial model determines the outcome to a large extent. Suppose, for example, that we analyse the skills shortages at the firm level. An employer notices that he can make large profits by producing a certain good, but the firm is hampered in its production because the supply of skilled labour for the production of this good or service is low. Looking at the possibilities of the product market, the individual employer may have an impression of the skills shortages the firm faces, which depends on the assumption that the firm will be able to serve the whole market. The reason that other firms do not produce for the same market may, however, be due to the fact that they also face these skills shortages. Asking other employers about their perceived skills shortages may therefore lead to double countings. Adding up the perceived skills shortages of all firms leads to an overestimation of the total skills shortages at a more aggregated industry or macro-economic level.

Analysing the situation at the level of the sector of industry may compensate for this. In that case, demand is determined for the sector as a whole, assuming that other sectors will not change their level of production. Again, however, if the goods produced in this sector have important substitutes or complements, the results of the analyses may be misleading. The same holds for cases where the skill concerned is also demanded in other sectors of industry. The determination of skills shortages therefore requires an explicit statement about the level of aggregation at which these have been measured.

\subsection{Summary: proposal for a set of indicators}

The discussion of the concept of skills shortages in this chapter shows that skills shortages can reveal themselves in different ways. In all these different manifestations there is, however, a situation of lost production that could have been 
avoided if adequate educational investments had taken place. It is therefore important for the measurement of skills shortages to treat these different types of skills shortages on an equal basis. In this final section, the main findings of the chapter are summarised, leading to a proposal for a set of indicators that can be used to catch any manifestation of skills shortages. Figure 1 provides an overview of the indicators that seem to be necessary to monitor skills shortages.

In the first place, all skills shortages can be characterised by a supply of the skill concerned that is below the normal or optimal quantity. There has been an underinvestment in education, training and experience in this specific skill. The quantitative shortage of skills is therefore the first indicator which seems to be relevant. Note, however, that this quantitative shortage does not necessarily relate to a certain category of formal skills, but may also relate to the number of people that have skills at a certain quality level. In practice, the quantitative measurement of actual rather than formal skills shortages will be hampered by practical limitations.

In addition, in order to measure the supply of skills, therefore requires measurement not only of the quantity, but also of the quality of these skills, so as to avoid judgements concerning skills shortages being based on labels in the form of diplomas only and not on the real contents of the skill concerned. Related to the supply of skills, an indication is therefore needed as to the quality of the skills in the form of productivity or the type and quality of work that can be performed.

Depending on whether market competition is at work or not, skills shortages can occur with, on the one hand, normal or relatively low and, on the other hand, relatively high wages. The costs of labour thus form a third relevant factor for the determination of the type of skills shortages. Classical skills shortages for which no adjustment processes have occurred are indicated by both a low quantity of supply in the skill concerned and a normal or relatively low wage. Only if employers are aware of the lost production possibilities, these classical skills shortages will also be perceived. An indicator of perceived skills shortages may therefore determine the cause of the shortages. In the case of structural barriers in demand, there will be no perceived skills shortages, while in the case of barriers on the supply side, due to structural barriers or due to information problems, employers will perceive the problems concerned. Note that it can be expected that the perceived skills shortages overestimate the actual skills shortages, since adequate anticipation of the situation by higher investments in these skills would have resulted in higher wages and lower demand. Theoretically, the actual skills shortages provide the most adequate picture of the situation, although perceived skills shortages will reveal much of the underlying actual skills shortages.

If firms compete for the scarce labour with the skills concerned, initially only wages will go up, without increasing supply. The combination of low supply with high wages therefore indicates a high-wage skills shortage. Although in this situation perceived skills shortages will not point to any problem, such wage competition does not solve the problem of underinvestment in education. 
Figure 1

A set of indicators for monitoring skills shortages

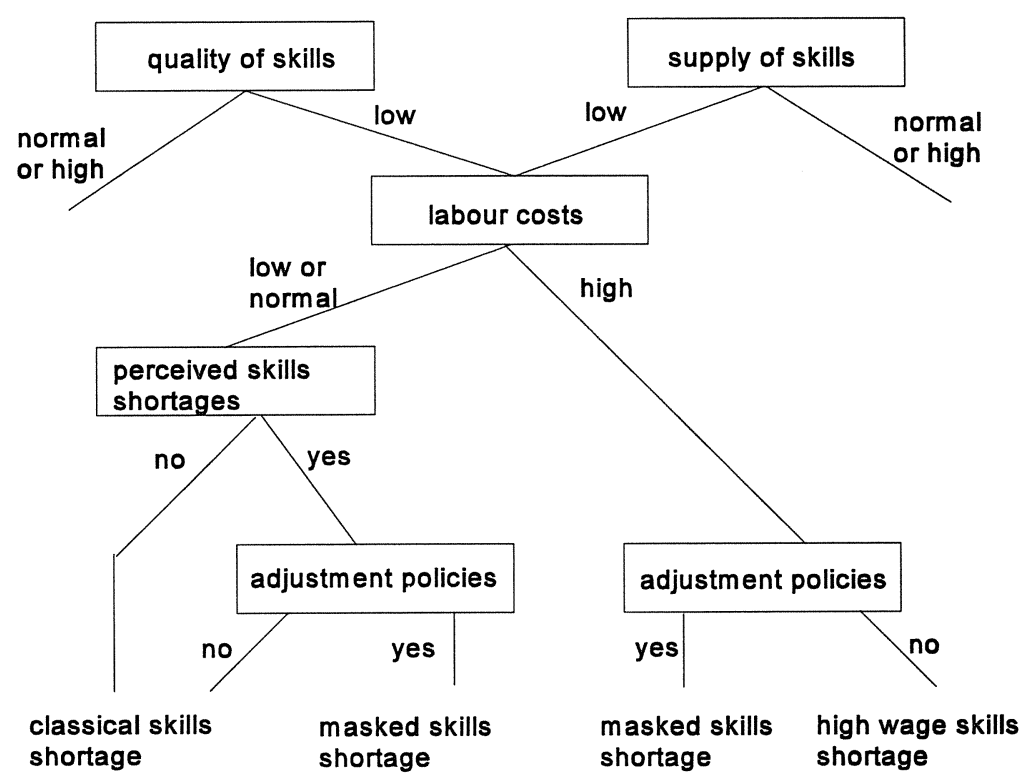

Eventually, when employers have become aware of the skills shortages, masked skills shortages indicated by policies to reduce the problem of skills shortages can be expected. It is therefore important to know whether additional adjustments have taken place to reduce the costs of the skills shortages. Such adjustments may be indicated by additional training of people with closely related skills, the occurrence of overtime work, et cetera. These additional adjustments provide insight in the consequences of skills shortages, but also show the creativity of employers in solving the problems concerned.

In order to be able to monitor every type of skills shortages, and to distinguish between the forms that skills shortages may take, the following set of indicators is proposed:

1. the quantitative shortage of skills

2. the quality of these skills

3. the costs at which the skills can be employed

4. the question whether employers perceive the shortages

5. the adjustment policies that employers take to reduce the costs of skills shortages 


\section{The observation of skills shortages}

\subsection{Introduction}

The theoretical framework developed in Chapter 2 and the derived aspects of skills shortages showed that, in order to get a complete overview of the occurrence and nature of skills shortages, five aspects are relevant. These are the size of a skills shortage in terms of quantities, the quality of the skills concerned in terms of productivity, the labour costs of the skills, the perception of employers concerning skills shortages, and possible adjustment policies which reduce the costs of skills shortages. These five aspects of skills shortages, if they can be measured, provide evidence for the occurrence of skills shortages, but also shed light on the character of the shortages.

The five aspects can be used as a starting point for the measurement of skills shortages. This theoretical framework ensures that different manifestations of skills shortages are interpreted in a consistent way. The set of indicators guarantees that all different manifestations of skills shortages are actually monitored. Furthermore, the theoretical framework makes it possible to link the concept of skills shortages to its possible effects on economic development, employment and unemployment. However, the theoretical concepts developed in the previous chapter must be transferred into concrete measures directly applicable in empirical research on skills shortages. Measurement of skills shortages requires observable phenomena. In this chapter, we will investigate in what way skills shortages lead to observable phenomena that enable measurement, and what limitations these classes of indicators have for measurement. This is the question of content validity, such as whether skills shortages can be correctly measured.

The fundamental problem in the measurement of skills shortages is that every measure of skills shortages is implicitly or explicitly related to a certain point of reference. The theoretical framework developed in the previous chapter enables to relate us these different points of reference to the different aspects of skills shortages. Specific indicators may therefore refer to different concepts of skills shortages. It is of crucial importance to analyse exactly what point of reference a certain indicator has, implicitly or explicitly. Furthermore, since these points of reference are often only implicitly present in a particular measurement instrument, attention must be paid to the question whether the theoretical point of reference is caught accurately. If, in practice, the point of reference deviates from its theoretical point, the quality of the measurement in terms of content validity may be seriously impeded.

As mentioned above, a distinction must be made between the theoretical concept of a skills shortage and its measurement. The analysis of different ways of measuring skills shortages makes it clear that every indicator is based on a certain assumption about the way in which skills shortages - i.e. deviations from the normal situation - 
become observable. In this section, we investigate different ways to link such measurable aspects with skills shortages. Firstly, the methods that are closely related to the perception of skills shortages are dealt with. These methods can be divided into observable search activities and surveys among employers with respect to their perception of the scarcity of certain skills. Secondly, methods are discussed that are based on the measurement or analysis of labour market behaviour. These methods can be divided into adjustment behaviour, comparisons and econometric models.

\subsection{The measurement of skills shortages based on the perception of employers}

\section{Search activities}

In a situation of classical skills shortages, demand exceeds supply at the prevailing labour market circumstances. It may be expected therefore that such skills shortages will lead to search activities of employers that are partially unsuccessful. For this reason, figures about these search activities, such as registered vacancies for workers who possess certain skills or advertisements in newspapers, may be indicative of such skills shortages.

Since the search behaviour concerned is decided upon at the firm level, the level of aggregation at which skills shortages are measured is implicitly the firm level. Furthermore, such expressions of open demand are probably based on the prevailing wage level. This presumes, however, that employers have an adequate view of the prevailing wage level and take this level as given. Of course this assumption is a major source of potential errors since vacancies that offer wages or fringe benefits below the current market level probably persist for a long time.

Figure 2

Reversed indication of skills shortages due to a diminishing usefulness of job search activities

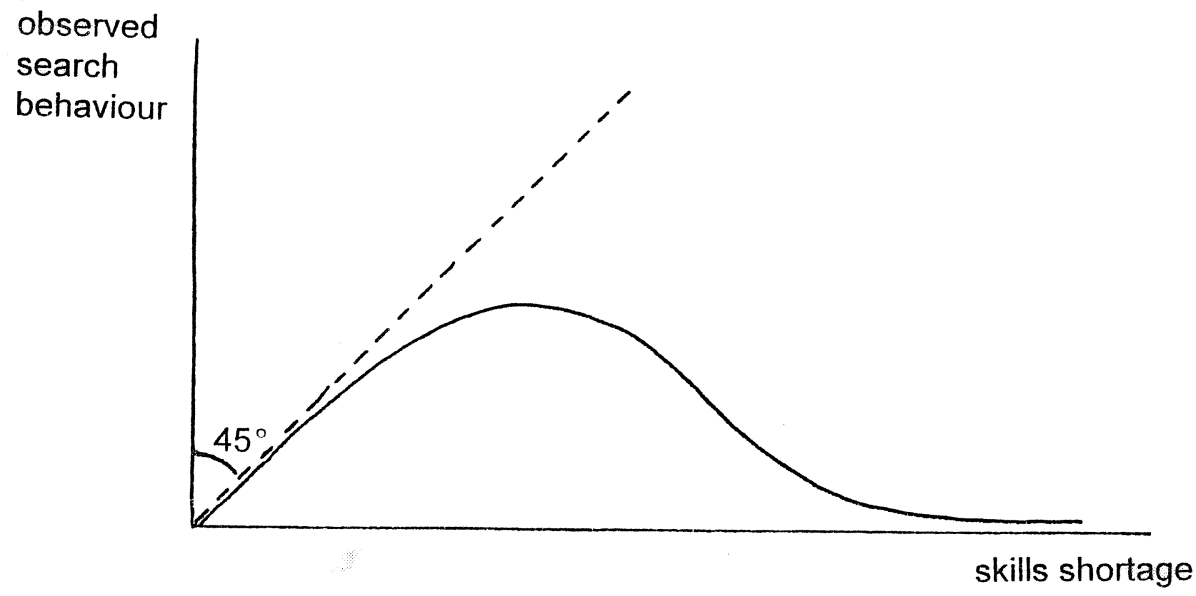


The main problem with direct expressions of skills shortages is that employers will probably not spend much energy searching people they will probably not find. Burdett and Cunningham (1994) show for example that the decision of a firm to publish a vacancy in the newspaper depends on both the probability that this advertisement will be successful and the costs of publication. Such a weighting of costs and benefits will in general have the result that employers are less inclined to spend money or time on the expression of open demand that has a low probability of being fulfilled. Figure 2 shows that, as a result, direct expressions of skills shortages will initially be closely related to the extent of skills shortages, but as skills shortages become larger this indicator will not follow this development and ultimately it even diminish again. Large skills shortages may therefore lead to a reversed indication problem. Experience with vacancy registration as collected in Muysken (1994a) indicates that problems with registration, caused by such anticipating behaviour of employers, seriously affect the usefulness of these data. At least certain correction techniques are needed to utilise such data.

\section{Surveys among employers concerning skills shortages}

An alternative for search behaviour as an expression of skills shortages is a survey among employers posing questions as to how many additional jobs they have for people with the skill concerned. As in the former case, this also provides information at the firm level. The reference point depends on the way the question is asked. Most existing surveys leave the wage level at which the demand is expressed implicitly. It therefore seems most appropriate to expect that employers will take the prevailing wage as given. Misperceptions of the wage level may, however, also occur in this case.

Besides questions about the extent of the demand, questions related to other aspects of skills shortages can also be asked. In the first place, this can be the question what wages an employer is prepared to pay to obtain more skilled labour. In addition, questions concerning the quality of the labour the employer is able to recruit or the skills shortages of the firm's workforce can be asked. Surveys may therefore provide a great deal of information that cannot be deduced from direct observations of search behaviour.

Compared to the direct observations of search behaviour, questionnaires are also more appropriate, because the results depend not so much upon cost-benefit decisions that the employer must make. Employers may therefore also report their perceived skills shortages in the survey in the case in which it is not efficient to undertake costly search activities. The question remains, however, what will be the quality of such answers if skills shortages become extremely large. Are employers able to quantify their individual needs for a certain type of skilled labour if, due to the scarcity of these skills, they have no experience with the productivity related to these skills? If certain skills are simply not available in a region or country, an employer may not even realise that it would be worthwhile for the firm to employ people with such skills. If skills shortages become very large also in surveys, the reverse 
indication problem sketched in Figure 2 may occur, which means that the indicators of skills shortages will decrease when skills shortages increase.

\subsection{The measurement of skills shortages based on observed behaviour}

\section{Adjustment behaviour as a reaction to skills shortages}

The two ways to measure skills shortages that have been discussed above both focus on the measurement of the difference between supply and demand of the skill concerned. They are therefore only appropriate for the measurement of classical skills shortages. As shown in Chapter 2, however, the economic consequences of skills shortages are still relevant even after wage adjustment. A high-wage skills shortages will therefore provide the employer with similar incentives to avoid these problems as classical skills shortages. To grasp both forms of skills shortages, it is useful to focus on the behavioural consequences of skills shortages, because as long as skills shortages imply costs, employers will always be interested in costsaving adjustments. One way to achieve this is to monitor the adjustment behaviour of the firm. It has been observed in the literature that excess demand can have various consequences in the behaviour of actors who are involved, such as the Confederation of British Industry/Manpower Services Commission (1987) and Trutko et al. (1991). As mentioned in Chapter 2, possible adjustment strategies that employers might follow to alleviate shortages include:

1. recruiting people with different educational backgrounds, with higher costs or lower productivity

2. providing additional training (i.e. more than usual) to workers with a second-best educational background

3. stimulating overtime of adequately skilled workers

4. substituting physical capital for human capital

5. stimulating interregional or international labour mobility

6. reducing production

This implies that the observation of such adjustment behaviour also indicates the presence of skills shortages.

However, the measurement of skills shortages by the observation of adjustment behaviour has two possible shortcomings. Firstly, specific adjustment may vary substantially between firms and skills concerned. Secondly, it is difficult to determine whether a certain policy of the firm must be regarded as normal or in fact indicates adjustments caused by shortages.

If there are no skills shortages, the use of these skills provide, by definition, the most efficient use of inputs for the production process. This means that alternatives as mentioned in the lists above will lead to higher costs for the same output or the same costs for lower output. A firm facing skills shortages will face additional costs while maintaining the normal situation. In that case, the firm accepts the lack of this skill 
among the workers recruited. In such a situation, other strategies may become less expensive. This implies that the use of these adjustment policies depends both on the extent of the skills shortages (measured in costs) and the costs of alternatives. Since the costs of alternatives may vary from case to case, similar skills shortages may lead to different adjustment policies, both in size and in character. The absence of one specific form of adjustment does therefore not necessarily mean that there are no skills shortages, as an employer may use other adjustments. Moreover, the extent of the use of the various adjustment instruments is not necessarily a good indicator for the extent of the skills shortages.

The second problem related to the measurement of skills shortages by adjustment policies is that, if firms train their technically skilled workers in commercial skills, it is not evident whether this should be considered as normal, or that this indicates that the market fails to deliver adequately skilled technicians. It must be decided for measurement purposes whether this behaviour is caused by the skills shortages for higher skilled personnel or that on-the-job training of lower skilled workers is the optimal strategy for a firm that is not induced by skills shortages of others. The crucial question for the use of adjustment behaviour as an indicator of skills shortages is therefore what can be considered as a normal level for the behaviour concerned. Skills shortage indicators based on adjustment behaviour can therefore only be used in combination with (i) information about the reason why firms perform such strategies, or (ii) by benchmarking by comparing training activities, overwork time, etc., to statistical averages, by analysing these figures in time, comparing occupations or similar economic sectors in different countries.

\section{Comparisons}

Measures based on the perception of skills shortages by employers only provide part of the information which is relevant for an analysis of the economic consequences of skills shortages. If employers themselves are not aware of the possibilities that certain skills may offer for the production of particular goods or services, methods based on perceptions do not suffice. Furthermore, the measurement of skills shortages at the level of a firm ignores the relevant influences at sector level or macro level and the interaction with the supply side of the market. The measurement of skills shortages by monitoring the adjustment behaviour of firms, does not fully overcome these limitations. It is therefore relevant to utilise indicators of skills shortages in which an explicit link is made with the interaction of supply and demand at different levels of aggregation in order to determine the quantities of skills that would have been available if adequate investments in human capital had been made. Determination of this point of reference would enable a comparison with the actual supply of skills.

A difficulty with the practical implementation of the theoretical concept of optimal educational investments is that such a measure requires information about the way supply and demand interact. This means that information is needed about the behaviour of firms and workers under hypothetical circumstances. Such an 
instrument requires (i) experience with such circumstances in different situations, or (ii) an econometric model in which the requested relationships are specified and estimated.

The methods of determining skills shortages on the basis of experience with different circumstances can be grouped under the heading of comparisons. Comparisons can be made:

1. between different years;

2. between different occupations, sectors of industry, or skills;

3 . between countries.

As was the case with the use of data on adjustment policies, the major difficulty with such comparisons will be to determine what situation can be regarded as normal. Additional information from perceived skills shortages may therefore be useful to determine such an ideal reference group. Without an absolute reference, comparisons regarding the utilisation of skills in time, among occupations, sectors of industry but mainly between countries, may provide very interesting information. For comparisons between countries, one may think of intra-European comparisons, indicating the relative positions of the various Member States, and comparisons between the EU and major competitors, such as Japan, the US or emerging economies. Intra-European comparison may provide insight in best practices in Europe. This was done, for example, by Borghans, Hughes and Smits (1997), who compared the occupational structure of Irish and Dutch workers with a particular educational background.

A major assumption on which comparisons are based is comparability of the situation. This means that it has to be assumed that all differences are caused by differences in investment behaviour and not by differences in natural resources. This may refer both to human capital and physical capital. If people in one country were more talented than in other countries, comparisons regarding their utilisation make no sense. The same would hold if one country had very favourable agricultural circumstances, while those in another country were poor. To allow for such differences, international comparisons must be made both at the macro and at the sector level.

The third major disadvantage of comparisons is that, in order to make data suitable for comparison, more or less rude classifications, and hence loss of detailed information, may be necessary. International comparisons, for example, must rely on international standards for levels of education. In most comparable data sources, such as EUROSTAT's Labour Force Survey, skills are reduced to formal qualifications, ignoring the subtle differences in quality of the skills concerned. The price of the wider scope of the analyses is then that the picture becomes less detailed.

Econometric models

An advantage of comparisons as a way of implementing a measure of equilibrium of 
skills shortages is that such a measure makes it possible to analyse at a level of aggregation above the individual firm, and also explicitly links the actual situation to the optimal situation. Such indicators of skills shortages not only point to problems of investment in human capital but also provide insight in the quantitative aspects of these shortages and the loss of economic development.

The comparative method depends, however, on the assumption of the comparability of different countries while the analysis of the possibilities is restricted to examples of best practices. More explicit modelling of the relevant economic relationships makes it possible to adjust for differences between countries with respect to their natural resources and enables explicit derivation of optimal investment in human capital. Cörvers, De Grip and Orbon (1995) have investigated an econometric model in which productivity is related to different levels of educated labour, from which they conclude that in the Netherlands productivity is hampered by a lack of workers at an intermediate vocational level.

Such econometric models are very restricted in the different types of skills they can distinguish. As a consequence, the concept of skills used becomes even more abstract than in the comparative method. In addition, econometric modelling always requires rather restrictive assumptions in order to keep the model manageable. However, as the example mentioned shows, econometric models could be relevant for the analysis of skills shortages for broader categories of skills. Due to their explicit and consistent reference to the consequences for productivity, these econometric models also seem to be well suited for the analysis of the relationship between skills shortages and economic development, employment and unemployment.

\subsection{Conclusion}

The investigation in this chapter indicates that there is a trade-off in the suitability between the various methods of measuring skills shortages. On the one hand, some measures based on employers' perception of skills shortages provide very detailed information but the methods are restricted by their lack of recognition of spill-over effects between firms, sectors of industry and the reactions on the supply side. Furthermore, due to the reversed indication problem in case of severe skills shortages, these methods probably only adequately measure marginal changes in the supply of certain skills. On the other hand, measures based on the analysis of observed behaviour related to skills shortages may provide a more consistent picture of skills shortages, in which the economic consequences of such shortages become more clear. These methods require comparisons or econometric models which usually refer to a higher degree of abstraction. As a result, much detailed information concerning specific aspects of skills will be lost. This leads to the conclusion that several methods of measuring skills shortages should be combined in order to obtain a full picture of the prevailing skills shortages. 


\section{The interpretation of different indicators}

\subsection{Overview of various measures used}

The previous chapter investigated the possibilities of measuring skills shortages in practice and discussed some of the problems that may occur in the practical implementation of these measures. This chapter gives an overview of fifteen different measures which have been used in economic and sociological literature to measure skills shortages. On the basis of the typology of Chapter 2 and the possibilities and problems of measuring skills shortages as discussed in Chapter 3 , these methods are classified. Specific problems regarding the implementation of these measures are also mentioned. At the end of the chapter, an inventory of the methods is made. On the basis of this inventory for each item in the set of proposed indicators for skills shortages, we will determine the preferences with respect to the various ways of measuring.

For each indicator, a diagram is provided containing the following elements. Firstly, one or more references are provided of publications in which the described method of measuring skills shortages is used. These references are merely examples. Often, there are many similar methods in economic and sociological literature. Secondly, under the heading of kind of measure, information is provided concerning the way in which the skills shortages are identified. This classification refers to the categories distinguished in Chapter 3. Thirdly, the theoretical concept - according to the proposed set of indicators - that is measured is mentioned. Fourthly, the indicators or survey questions used are mentioned. Following these four main properties, information is provided about the level of aggregation, the reference situation, demand, supply and the basic assumption. The level of aggregation indicates at what level the measurement is consistent. If this is the firm level, this does not necessarily mean that information is provided at that level, but that the data are collected from the point of view of the individual firm, ignoring possible reactions of other firms. The reference situation indicates the situation which is implicitly or explicitly regarded as normal by the indicator. The definition of skills shortages implies that supply and demand together determine the difference between the actual and optimal supply of skills. For the measurement of skills shortages it would be desirable if the point of reference was based on the 'ideal' demand and supply in which the costs of education and training are balanced by their benefits. Many indicators, however, are based on demand perceived by employers and do not take into account the interaction with supply. Demand provides information about the way in which demand is determined. Supply provides similar information about the supply side. Finally, basic assumptions provide the assumptions that are used to operationalise the concept. Both the reference situation, demand, supply and the basic assumptions show possible shortcomings. If such is not evident, these shortcomings are indicated by 0,0 , etc. 
1. Open vacancies registered at Public Employment Offices

Used by e.g.

Kind of measure

Theoretical concept

Indicators/Questions

Level of aggregation

Reference situation

Demand

Supply

Basic assumptions
Brusten, De Coninck and Van Schel (1994)

Search behaviour

Perceived skills shortages

Number of vacancies registered

Firm level

The demand at the prevailing wage level

- Employers' misperceptions of the market wage may lead to systematic bias in observation

As perceived by the employers

Not relevant

A firm reports every required worker with the skill concerned

- A firm that anticipates that the probability that the Public Employment Office will fulfil the vacancy is very low, may decide not to report the vacancy (revised indication problem)

(2) A firm that has several equivalent vacancies may report only one vacancy as long as this is still open

(3) A firm may report to several employment agencies or several Employment Services, e.g. in different regions, which may lead to double counting. 
2. Corrected registered vacancies

Explanation

Used by e.g.

Kind of measure

Theoretical concept

Indicators/questions

Level of aggregation

Reference situation

Demand

Supply

Basic assumption
Since not all vacancies are reported to the Public Employment Office, and most importantly, since the coverage ratios differ between occupations, corrections are made in which the detailed information which is available from the registration of the Employment Office is corrected by means of a model for coverage, by using other sources of data Muysken et al. (1994), Schettkat (1994) Search behaviour, econometric model Perceived skills shortages Number of registered vacancies Observed vacancies

Advertisements

Duration of vacancies

Firm level

The demand at the prevailing wage level

(1) Employers' misperceptions of market wage may lead to systematic bias in observation

As perceived by the employers

Not relevant

Ratio between actual number of vacancies and registered vacancies can adequately be predicted by the model.

1 Model misspecifications, e.g. due to a high level of aggregation or due to the assumption that the coverage ratio will not change in time, may hamper the quality of the correction 
3. Assessment of job advertisements

Used by e.g.

Kind of measure

Theoretical concept

Indicators/questions

Level of aggregation

Reference situation

Demand curve

Supply curve

Basic assumption
Bastianen and Van Ours (1990)

Search behaviour

Perceived skills shortages

Number of advertisements

Firm level

The demand at the prevailing wage level

(1) Employer's misperception of market wage may lead to systematic bias in observation

As perceived by employers

Not relevant

All vacancies are advertised in newspapers or journals.

1 A firm that anticipates that the probability of fulfilling the vacancy is very low, may not advertise in order to diminish costs

2. A firm that has several equivalent vacancies may advertise only one vacancy

(3) Vacancies may be published in several journals

(4) A firm may not use an advertisement, but use other ways of recruitment

5 The departure of one worker may lead to a chain of vacancies due to job-to-job mobility 
4. (Occupational) unemployment rate

Used by e.g.

Kind of measure

Theoretical concept

Indicators/questions

Level of aggregation

Reference situation

Demand

Supply

Basic assumption
Cohen (1995)

Search behaviour, comparison between

occupations

Perceived skills shortages

Unemployment rate

Macro level

Some kind of 'natural' unemployment

- Meaning of this natural unemployment is not clear

As perceived by employers

As perceived by students/workers

The unemployment rate fluctuates around the natural rate and is low when demand exceeds supply. Hence, a comparison of unemployment rates by skill or occupations gives an indication of the relative shortage of skills.

(1) Assumed relationship between skills shortages and unemployment is rather indirect

2) Unemployment may be influenced by other factors than skills shortages

3) 'Unemployment per occupation' ignores occupational mobility of skills 
5. Labour turnover/replacement demand surveys

Used by e.g.

Kind of measure

Theoretical concept

Indicators/questions

Level of aggregation

Reference situation

Demand

Supply

Basic assumption

\section{Cohen (1995)}

Search behaviour; comparison in time

Perceived skills shortages

Labour turnover

Total replacement demand

Firm level

A situation of normal labour turnover

- Determination of normal labour turnover is difficult

As perceived by employers

As perceived by workers

The higher the skills shortages, the higher the labour turnover or replacement demand.

1) Assumed relationship between skills shortage and labour turnover is not evident

(2) Labour turnover may be influenced by other factors 
6. Vacancies in firms

Used by e.g.

Kind of measure

Theoretical concept

Indicators/questions

Level of aggregation

Reference situation

Demand curve

Supply curve

Basic assumption
Teulings (1995); Holzer (1994); Van Bastelaar and Laan (1994)

Survey among employers

Perceived skills shortages

Teulings (1995)

Number of vacancies relative to employment

Number of vacancies hard to fill relative to employment

Number of unrealised jobs

Share of vacancies open $<1$ year

Share of vacancies 0-1 month

No extension due to tightness

Firm level

The demand at the prevailing wage level

- Employers' misperceptions of the market wage may lead to systematic bias in observation

As perceived by the employers Not relevant

A firm reports in the survey every required worker with the skill concerned

- Employers have an incentive to exaggerate the shortages since they have an interest in the outcome of the survey 
7. Technology-based assessments of changing skills requirements: qualitative approach

\begin{tabular}{|c|c|}
\hline Used by e.g. & $\begin{array}{l}\text { Kern and Schumann (1990); Van Dam and } \\
\text { Van der Velden (1991); Wilkinson (1993); } \\
\text { Webster (1990); Liff (1990) }\end{array}$ \\
\hline Kind of measure & Survey among employers \\
\hline Theoretical concept & Perceived future skills shortages \\
\hline Indicators/questions & Training needs \\
\hline Level of aggregation & Firm level, sector level \\
\hline Reference situation & $\begin{array}{l}\text { All new technologies can be introduced } \\
\text { without any additional training }\end{array}$ \\
\hline Demand & As required for the new technology \\
\hline Supply & Actual supply \\
\hline Basic assumption & $\begin{array}{l}\text { Expected changes in the technology used } \\
\text { determine the future skills shortages } \\
\text { - It is not clear to what extent expectations } \\
\text { about the introduction of new technologies } \\
\text { are already influenced by the availability } \\
\text { of skills }\end{array}$ \\
\hline & $\begin{array}{l}\text { (2) Developments at the supply side are } \\
\text { ignored }\end{array}$ \\
\hline & $\begin{array}{l}\text { (3) It is very difficult to aggregate the result to } \\
\text { the macro level }\end{array}$ \\
\hline
\end{tabular}


8. Curriculum conference

Used by e.g.

Kind of measure

Theoretical concept

Indicators/questions

Level of aggregation

Reference situation

Demand

Supply

Basic assumption
Frey (1982); Mulder (1992)

Survey of employers and other experts

Perceived skills shortages

What skills shortages are expected?

Occupations

Determined by the opinion of the expert

(1) Reference situation is too vague to be included in the theoretical framework

As perceived by experts

As perceived by experts

Experts are able to determine what changes in a curriculum are feasible and will generate larger benefits from an economic point of view

(1) It will be difficult to determine whether changes in a curriculum are feasible for all students concerned

(2) It is very difficult to aggregate the results to the macro level 
9. Detecting adjustment mechanisms by firms in response to skills shortages

Used by e.g.

Kind of measure

Theoretical concept

Indicators/questions

Level of aggregation

Reference situation

Demand

Supply

Basic assumption
Trutko (1991); Senker (1992); Praat,

Smulders and Van Werkhoven (1996)

Adjustment behaviour; Survey of employers

Adjustment behaviour

Trutko (1991)

Does the firm as a result of skills shortages:

- Increase recruiting effort

- Increase use of overtime

- Reduce minimum job qualifications

- Restructure work to use workers in other occupations

- Substitute machinery for labour

- Train workers

- Improve working conditions

- Offer bonuses to new employees

- Improve wages and fringe benefits

- Contract out work

- Turn down work

Firm level

Situation in which no adjustments are needed.

(1) It is difficult to determine what degree of firm training etc. can be regarded as normal

As perceived by employers

Not relevant

Skills shortage lead to alternative policies of firms

(1) Type of adjustments may vary between firms 
10. Survey of employees or school-leavers

Used by e.g.

Kind of measure

Theoretical concept

Indicators/questions

Level of aggregation

Reference situation

Demand

Supply

Basic assumption
Van Smoorenburg and Van der Velden (1995); Van de Loo, Hoevenberg and Van der Velden (1995); Nijhof (1996)

Survey of employees

Quality of skills, labour costs, adjustment behaviour

- The kind of jobs the respondents have

- The wages they earn

- The curriculum aspects that are important for the job and the aspects that need more attention

- The perceived match between skills and job

- Adjustment policies of the firm such as additional training

Individual worker

Determined by the opinion of the individual worker

- Conclusions regarding skills shortages can only be drawn if a objective reference situation is constructed. Comparisons between types of skills, in time and between countries seem to be solutions for this.

Only jobs in which employees are actually working

Not relevant 
11. International comparisons of matched samples of firms

Explanation

Used by e.g.

Kind of measure

Theoretical concept

Indicators/questions

Level of aggregation

Reference situation

Demand curve

Supply curve

Basic assumption
A matched sample consists of firms in different countries that are comparable in the goods or services that are produced, size, etc. Detailed case studies of these firms indicate differences in the way in which the work is organised and differences in the quality of production

Marsden and Ryan (1991); Steedman (1987)

International comparisons, survey of employers

Productivity and quality of the skills

Productivity level

Required and available skills

Background characteristics (i.e. production method; regulations etc.)

Firm level

The most productive firm (best practice)

Not relevant

Not relevant

Differences in skills can be identified by the comparison of matched firms

1 Skills shortages will also influence the goods and services that are produced

(2) The allocation of skills across sectors of industry may differ between countries

(3) It is very difficult to aggregate the results to the macro level 
12. Rate-of-return analysis

Used by e.g.

Kind of measure

Theoretical concept

Indicators/questions

Level of aggregation

Reference situation

Demand

Supply

Basic assumption
Psacharapoulos (1981)

Comparison in time, between countries, between types of education, between occupations, econometric model

Labour costs

Present value of costs and benefits of investment in education

Macro level

Rate of return equal to interest rate

As perceived by employers

Determined by the present value of costs and benefits

When the individual rate of return for investment in human capital is higher than the interest rate, wage costs are above normal situation

- Supply decisions are completely determined by financial aspects 
13. Comparison of available skills between countries

Used by e.g.

Kind of measure

Theoretical concept

Level of aggregation

Reference situation

Demand

Supply

Basic assumption
Education at a glance, OECD (1996b)

Comparison between countries

Quantitative skills shortages

Macro level

Best practice

1 More and higher skills are assumed to reflect a better situation, although no analysis of costs and benefits is made.

Not relevant

Best practice

Each country can obtain the same quantities of skills 
14. Labour market forecasts

Used by e.g.

Kind of measure

Theoretical concept

Level of aggregation

Reference situation

Demand

Supply

Basic assumption
Research Centre for Education and the Labour Market (Netherlands ROA, 1995a,b); Institute for Economic Research (UK); Institut für Arbeitsmarkt und Berufsforschung (Germany) Bureau of Labor Statistics (USA)

Econometric modelling and comparison in time

Skills shortages in quantities

Per sector, occupation and type of education, consistent at the macro level

Actual allocation of labour

1 This methods point in the first place at changes in time of the scarcity of certain categories of labour. No absolute point of reference is used.

Based on actual recruitment behaviour Actual supply behaviour

Demand for certain skills is primarily determined by employment developments in sectors of industry, shifts in the occupational structure of sectors of industry, and shifts in the educational structure of occupations (together with replacement demand) 
15. Models of production related to development of skills

Explanation

Used by e.g.

Kind of measure

Theoretical concept

Level of aggregation

Reference situation

Demand

Supply

Basic assumption
This approach uses a production function in which the average productivity level is explained by an efficiency parameter, physical and human capital, and the elasticity of physical capital and labour, respectively.

Cörvers (1997); Daley (1986); Davies and Caves (1987); Cörvers and De Grip (1997)

Econometric modelling

Skills shortages in quantities

Sector level

Situation of optimal economic output

Deduced from optimal productivity

Best practice in comparison with other countries

A relative shortage of a certain skills leads to a lower average productivity level.

(1) Data limitations strongly restrict disaggregation of model

(2) Results depend on the correctness of the model specification 


\subsection{Preferred instruments for measurement}

In Chapter 2, a set of indicators for the measurement of skills shortages was proposed. The use of this set of indicators guarantees that all aspects of skills shortages that seem relevant according to the theoretical framework can be detected. On the basis of the investigation of different methods for the measurement of skills shortages in the previous diagrams, this chapter is concluded by a list of preferred tools of measurement for each indicator in the proposed set.

\section{Quantitative skills shortages}

The investigation of indicators used in the various studies on skills shortages contains three measures that provide information about the qualitative dimension of skills shortages. Most indicators that provide quantitative information concentrate on perceived skills shortages. Two of these three methods are econometric models: models of production related to the development of skills and labour market forecasting models. As a third method, international comparisons of the number of skills available can be used. Since the production function models explicitly link skills shortages to production, these seem to constitute the most adequate instrument for the detection of the qualitative dimension of skills shortages. Two disadvantages of this approach are that the use of an econometric model makes the measurement complex and the chosen specification partly affects the outcome. In cases where no econometric analyses are performed, a direct international comparison of the available skills as a means of benchmarking may be a good alternative. Since differences in the sectoral structure may be relevant for the differences in skills available, adjustments can be made for the national composition of employment.

\section{The quality of the skills}

Since many indicators for skills shortages in practice rely on classifications of skills that are often based on formal qualifications, rather than the actual skills people have, it is important to complement the analyses of skills shortages with an indicator for the quality of the skills concerned. The investigation of indicators suggests three ways to obtain such information. First of all, case studies based on matched samples provide highly detailed and interesting information in this respect. For a study at the macro level, this method is not feasible. The two other alternatives seem more appropriate. Firstly, in a survey among workers or school-leavers, questions can be asked about the skills required for the job in which a person is employed and about the match between education and experience and this job. This explain the fact that when comparing different countries, people with the same formal qualifications find jobs at lower levels (Borghans, Hughes and Smits, 1997) or have more problems in their functioning in the same jobs. Secondly, econometric analyses of the relationship between skills and productivity may show different productivity levels between countries, even if corrections are made for the availability of skills. The first method makes it possible to analyse at a low level of aggregation, while the second method has the advantage of the explicit link with productivity. In 
practice such econometric models are only feasible at a high level of aggregation.

\section{The cost at which skills can be employed}

The study of specific indicators for skills shortages provides two methods for the measurement of labour costs. In the first place, a survey among employers or school-leavers can provide this information. As an alternative, a rate of return analysis can be used. These rates rely on the same data sources. Since these reduce the benefits of education and training to pecuniary rewards, they provide an interpretation that may be regarded as too restricted. For this reason, a survey in which wage information is collected is preferred.

\section{The perception of skills shortages by employers}

The investigation of specific indicators for skills shortages provides many indicators for perceived skills shortages. Three groups can be distinguished. Firstly, some indicators are based on vacancy registers or vacancy surveys. Secondly, surveys among employers can also be used to ask directly for perceived skills shortages. Thirdly, unemployment rates or labour turnover rates may indirectly indicate perceived skills shortages. For this third method, the assumed relationship between the indicator used and the perceived skills shortages is crucial, and hence large measurement errors may be introduced. Direct measurements are therefore preferred. The registration of vacancies may, however, be hampered by varying coverage ratios, while surveys on skills shortages are probably influenced by the interest employers have in the results of the survey. For the measurement of perceived skills shortages, a vacancy survey or a method to correct the registered vacancies is therefore preferred.

\section{Adjustment policies}

Adjustment policies of firms can be measured by a survey. This survey may be held among employers or among employees. Since several forms of adjustment policies may not be perceived by employees, a surveys among employers is preferred.

Table 1 summarises the above-mentioned preferences for the measurement tool for five aspects distinguished in the proposed set of indicators.

The table shows that three sources of data together constitute all elements needed to complete the set of indicators proposed. These preferred tools of measurement are:

- Model of production related to utilisation of skills

- Survey of employers or school-leavers

- Vacancy survey 
Table 1

List of preferred instruments to measure five aspects in the set of proposed indicators for skills shortages

1 Quantitative skills shortages

2 The quality of the skills

3 The labour costs

4 Perceived skills shortages

5 Adjustment policies
1 Model of production related to the utilisation of skills

2 International comparison of number of skills available

1 Survey of employees or school-leavers

2 Model of production related to the utilisation of skills

1 Survey of employees or school-leavers

1 Vacancy survey

2 Corrected registered vacancies

1 Survey of employers

2 Survey of employees or school-leavers

These three sources also combine the advantages of econometric models with the advantages of survey data. Models will enable a close link with the theoretical framework provided in Chapter 2. As a consequence, the implications of skills shortages for economic growth, employment and unemployment can be analysed better on the basis of this approach. Direct survey data, on the other hand, provide the possibility of obtaining information on a detailed level of aggregation, in which no assumptions about the structure of the relationships need to be made. The combination of an econometric model in which production is related to the input of skills, and detailed survey data therefore provides the best overview of the socioeconomic problems related with skills shortages. 


\section{Outline for a research programme}

\subsection{Introduction}

In the previous chapters, we looked at the concept of skills shortages and analysed the ways in which skills shortages can be measured. This has led to a proposal for a set of indicators to measure skills shortages, as summarised in Figure 1. Table 1 provided preferences for the way in which these indicators can be measured. The main point in these analyses is that skills shortages should be defined as situations of lost production caused by underinvestment (or inefficient investment) in the acquisition of skills by initial education, on-the-job training and experience. However, it is not the perceived shortage of skills that hampers economic development, since employers may not be aware of the productivity potential of certain skills. Furthermore, competition for scarce skills or firm adjustment policies to cope with skills shortages may result in a situation in which no open discrepancy between the demand and supply for certain skills is observed but in which nevertheless the lost production, as mentioned above, occurs.

The set of indicators for skills shortages that has been proposed, is therefore composed in such a way that all different manifestations of skills shortages are covered by at least one of the indicators. The proposed set of indicators can therefore be regarded as a checklist which, as a whole, may show the problems of skills shortages.

The close relationship that has been established between skills shortages and lost production also makes it possible to create a direct link between skills shortages and economic growth, employment and unemployment. In this section we will analyse this relationship between, on the one hand, the skills shortages concept as defined in Chapter 2 and operationalised in Chapter 4, and, on the other hand, the possible obstructions of economic developments. On the basis of these interactions, a research programme will be outlined which aims at an empirical study of the effect of skills shortages in the European Union on economic development, employment and unemployment.

\subsection{Skills shortages and economic development, employment and unemploy- ment}

Lost production due to the non-recruitment of people with suitable skills, which is the major characteristic of skills shortages, will of course by definition hamper economic development measured in terms of production and productivity growth. Skills shortages do not necessarily lead to reduced employment growth or to unemployment. Lost production due to skills shortages is not caused by the fact that part of the labour force is not working, but by the fact that - even if it works full time - it does not deliver the production that would have resulted if there had been more appropriate skills. Possible effects on employment and unemployment are therefore 
indirect consequences of skills shortages. These effects on employment and unemployment will depend on two aspects:

1. Employment effects depend on the type of skills shortages concerned, i.e. the way in which the skills shortages affect employers' behaviour.

2. The effects on employment and unemployment will depend on the role which the skills concerned play for the economic development.

Both aspects will be dealt with in detail below.

\section{Different forms of skills shortages}

As has been shown in Chapter 2, skills shortages may have different forms. In a classical skills shortage, which occurs if the skills people have do not meet the requirements of employers, a situation results in which demand for individuals who possess the appropriate skills exceeds the supply, while those who have skills that are less required by employers (or labour that lacks certain skills) are not employed. Such an imbalance between available skills and required skills, without any adjustment in the production process, implies an excess demand for some skills and an excess supply for other skills. Consequently, as a result of the matching process on the labour market, the workers with the skills in excess demand will face no or a very low level of unemployment, while the group with excess supply faces a high unemployment rate. At the macro level, this will result in the simultaneous occurrence of unemployment and vacancies as pointed out by, for example, Bean and Pissarides (1991), and Sneessens (1994). The level of unemployment will be structurally higher than in the case of a good match between the available and required skills.

Apart from the classical case, skills shortages may also lead to reactions from employers in the form of an intensified competition on the labour market or adjustment policies to diminish the consequences of these shortages. Intensified competition among employers is an attempt to recruit the scarce skills concerned. Such competition may induce wage increases for skills in excess demand, but also more money and energy may be spent on recruitment efforts. The consequence of both practices will be that, due to the high costs, the skills concerned will become unattractive or unreachable for certain employers. For these employers, the costs are no longer compensated by the benefits. The demand for these skills will decrease and only the employers who are prepared to pay high wages or to intensify recruitment efforts will actually employ the individuals with the skills concerned.

Production of the goods or services concerned will diminish as a consequence. The competition does not solve the skills shortages but regulates the distribution of its effects. If similar competition processes lower the costs of recruitment for the skills which are in excess supply, inversely the production of goods and services associated with these skills will increase. Overall, there will be a negative effect on production at the macro level. 
Alternatively, employers may react to skills shortages by implementing adjustment policies in their production process. For example, production plans may be changed so that a firm reorganises the production process in a way in which the shortage of the skills concerned is less obstructive. This may even result in the production of different goods, or products of a lower quality. Firms can also react to skills shortages by recruiting individuals with related skills, accepting lower productivity or additional training costs. In the first example of adjustment policies, production tends to shift from goods and services requiring specific skills related to product or service quality, to goods and services that do not require such skills. In the second example, the type of goods produced does not change, but the productivity at which the process takes place decreases. In the case of training as an adjustment policy, or if people with partly inadequate skills obtain relevant experience, the skills shortages will disappear after some time. For the investigation of the economic consequences of skills shortages, it is important to note that a firm will have to produce the goods and services concerned at a lower productivity, or will have to diminish the production of the goods concerned itself.

This means that the economy becomes less productive for the same goods or that the economy switches its focus to other, lower-quality goods and services, which require less input of skills (Steedman and Wagner, 1987, and Ryan, 1991).

\section{The role of skills}

The contribution of skills to the production process can be distinguished in four different effects (see Cörvers, 1994):

- the worker effect,

- the allocative effect,

- the diffusion effect,

- the research effect.

The worker effect (Welch, 1970) implies that, given a certain task, workers with relevant skills will perform this task with a higher level of productivity. Skills increase the effective labour input from the hours worked. Welch (1970) argues that for complex work, the marginal contribution of improved skills will be larger than for less complex work. The complexity may both refer to the production technique and to the organisational setting in which production takes place. The more complex the work, the more 'room' is left for the worker effect to improve the efficiency of production. In case of skills shortages, the worker effect indicates a direct loss of production in the goods and services produced by the person involved. Moreover, as Welch suggests, skills shortages in 'high tech' sectors have a greater negative effect on the total level of production than skills shortages in 'low tech' sectors.

The allocative effect (Welch, 1970, Ram, 1980) adds to this that better skilled workers will reach a greater allocative efficiency in combining the input factor in the production process. This means that workers with more allocative skills will not necessarily have a larger productivity, but will use the labour and capital available to 
them more efficiently. They will spend more on projects that have larger revenues. As Ram (1980) states: 'Education generally has the effect of lowering the (marginal) costs of acquiring production-related information, and of raising the (marginal) benefits of such information'. Examples of occupations in which the allocative effect may be large are managerial occupations in which individuals take decisions about the efforts of their personnel, professional occupations in which workers are expected to decide effectively upon the way a certain project should be carried out, or commercial occupations in which workers take decisions on sales or purchase efforts. As a consequence, the allocative effect implies that the relevance of the skills concerned is not limited to the activities of the worker himself, but that these skills improve the productivity of a group of workers related to the activities they coordinate. Skills shortages for occupations with large allocative effects may therefore not only hamper the activities of the labour in excess demand itself, but may also reduce the productivity of these related occupations. Skills shortages for these key occupations will therefore lead to a lower demand for other skills.

The diffusion effect stresses that higher skilled workers are more capable of adapting to new technological developments and will introduce these more quickly (see e.g. Nelson and Phelps, 1966 and Bartel and Lichtenberg, 1987). Again, this refers not only to the introduction of new production techniques and new products, but also to organisational innovations induced by e.g. ISO certification or total quality management (see De Grip, Van Smoorenburg, Borghans and Jonker, 1997). A higher level of skills increases the ability to discriminate between more and less profitable innovations, and reduces the uncertainty about investment decisions with regard to new production processes, new products and organisational innovations.

The research effect refers to the role of skills as an input factor in research and development. R\&D in turn, is a key factor for technological progress and productivity growth, as explained in the theory of endogenous growth (see e.g. Romer, 1990 and Grossman and Helpman, 1992). Both the diffusion effect and the research effect imply that skills shortages in occupations for which these effects are relevant lead to a reduced economic growth both in the economic sector concerned (diffusion effect) and in the economy as a whole (research effect). Although this research effect may also refer to organisational innovations, the higher technical occupations, and in particular the R\&D jobs, are usually regarded as the clearest examples of such occupations.

\section{Implications for production and employment}

Skills shortages will always reduce economic development. The effects on employment and unemployment may, however, depend on the type of skills shortages and the effect of the skills on productivity. As mentioned above, high-wage skills shortages will lead to a specialisation in low-quality goods and services. Depending on the adjustment policies of the firm, masked skills shortages can also lead to such specialisation in lower quality, but may equally well lead to lower productivity in producing the same good and services. Table 2 provides an overview 


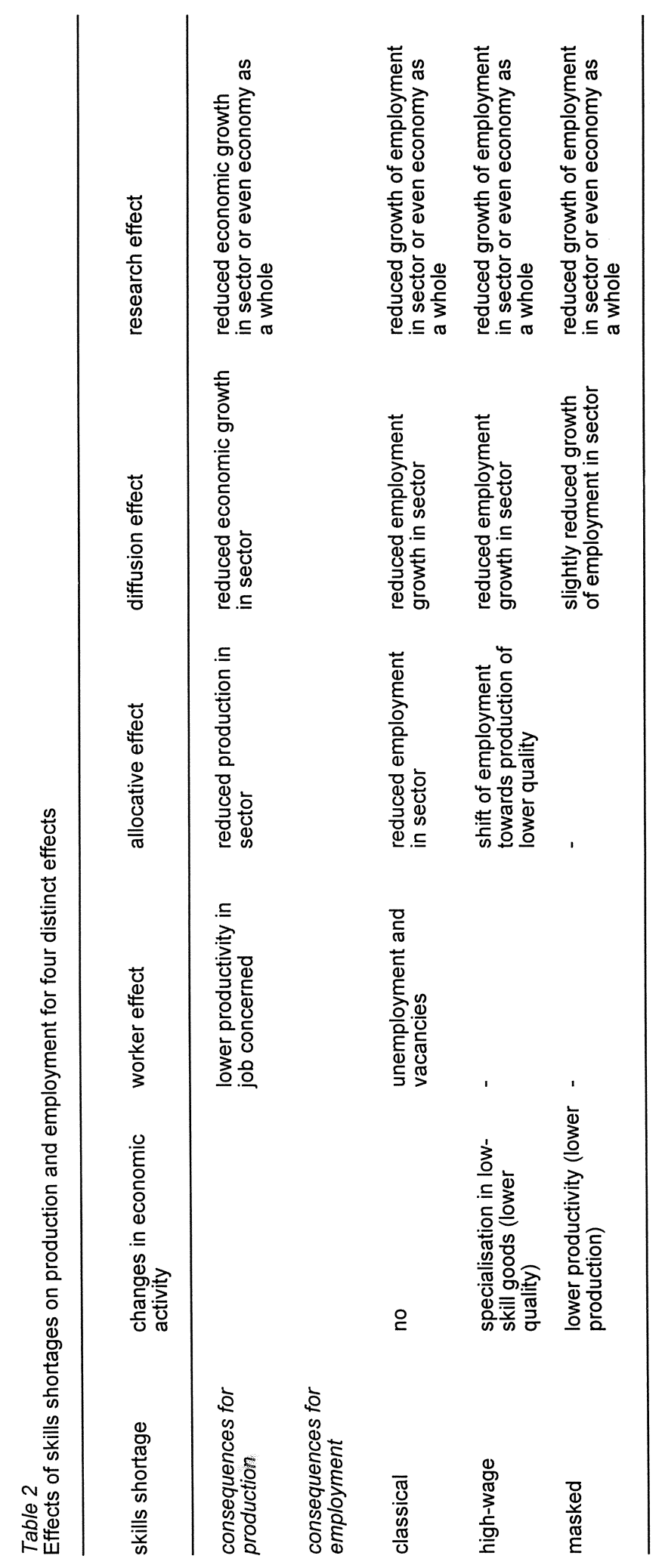


of the consequences for production and employment of skills shortages with respect to the four effects of skills. For the consequences for employment, a distinction has been made between three situations: a classical, a high-wage and a masked skills shortage. A classical skills shortage will not hamper the economic activities for which the skills concerned are used, but does not change the structure of economic activity. A high-wage skills shortage - or a masked skills shortage if adjustments are made in production - will stimulate low-skill production at the expense of high-skilled goods and services. A masked skills shortage will in general lead to a lower productivity of the same goods and services. Most adjustment possibilities that a firm may use will require additional costs or lower productivity of the workers concerned. The reduction of productivity may be caused by the fact that available skills are less appropriate, or by absence as a consequence of additional training.

If skills affect productivity only by means of the worker effect, the effects on production and employment are limited. Since the skills concerned are no key qualifications, only a reduction of the production by the worker concerned can be expected. With respect to the employment consequences, we can only expect an increase in structural unemployment for a classical skills shortage, i.e. unemployment and vacancies will coexist. If employers react to the skills shortages by intensifying competition on the labour market or by adjusting the production process, the effect on productivity will remain, but the reactions will compensate the effects on employment and unemployment.

If skills shortages have an allocative effect, the consequences for production and employment increase. Since the allocative effect is connected with some skills that are crucial for the functioning of the firm as a whole, a shortage for the skills concerned will not only reduce the direct productivity of these workers, but will also hamper the functioning of the workers that depend on the instructions of the individuals who have these allocative skills, such as managers and professionals. This will lead to reduced production of the sector as a whole. The effects on employment depend on the type of skills shortages concerned. In the case of classical skills shortages, employment in the sector affected by the shortage will simply reduce. If higher wages lead to a specialisation in low-skill goods, employment may shift to the production of these goods. For the competitiveness of the economy, this implies that although employment itself is perhaps not reduced, the economy becomes more dependent on the production of goods and services that are less knowledge-intensive. This may increase competition with countries in which wages are relatively low. Such increased competition with low-pay countries forces the wages to go down in order to avoid high unemployment rates. If adjustment policies lead to the production of the same quality of goods, the effects will be limited to lower productivity. Production remains focussed on knowledge-based goods and services. Similar wage adjustments may be required, however, to maintain international competitiveness.

In the case of the diffusion effect, skills shortages not only reduce the production level, but also economic growth. Absence of the crucial skills will hamper the 
diffusion of relevant new technologies, which will lead to a situation in which the accumulation of knowledge lags behind. As a consequence, employment growth will also lag behind in these sectors. In the case of specialisation in low-skill goods, this may be compensated by growing employment in the production of these goods. Only in the situation of lower productivity for the same goods that may result from masked skills shortages, diffusion may also remain partly intact. This will be the case if workers who received additional training to compensate for the skills shortages, are able to implement new technologies. The danger exists, however, that those who received additional training to compensate for skills shortages of others, will in the first place be able to take over the every-day production tasks, while their skills do not suffice to fulfil the tasks related to the implementation of technological innovation.

Lastly, skills shortages related to the research effect will have the largest impact on economic development. Since innovations made by individuals who have these research skills can be important for the productivity growth of the sector concerned, but by diffusion processes also for the economy as a whole, skills shortages in research skills may hamper both productivity growth and employment growth in the economy as a whole. In addition, adjustment policies will not reduce these effects since it is not likely that any of the adjustment policies will be able to compensate for shortages in these R\&D skills. The only alternative that may improve research and development in the case of skills shortages, is mobility of foreign workers to R\&D jobs in the country concerned.

\subsection{Outline of the research programme}

In this report, (1) the concept of skills shortages has been investigated, (2) the way in which skills shortages can be measured has been analysed, and (3) the relationship between skills shortages and economic development, employment and unemployment has been discussed. These three elements together constitute a useful point of departure for a research programme with respect to the impact of skills shortages on economic development, employment and unemployment in de European Union. In this final section, a proposal for such a research programme is sketched.

In economic literature, production function models in which the relationship between the input of certain categories of labour explains the productivity in a certain sector of industry (see e.g. Cörvers, 1997) seem to be the most appropriate approach for the research programme concerned. The reason for this is that lost production is at the heart of the concept of skills shortages. But such production function models do, on the one hand, not take into account the qualitative aspects of the concept skills. The input in the investigated production process is defined in terms of formal qualifications. The reason for this is that data on formal qualifications can be obtained relatively easily. In order to analyse the significance of skills acquired by on-the-job training and experience, but also to include possible differences in the quality of skills related to certain formal qualifications, this research programme must 
make the effort to collect data based on the set of indicators concerning skills shortages as proposed in this report. On the basis of this additional information, the analyses of the productivity effects of skills can be greatly enriched. Adequate monitoring of skills shortages in an internationally comparative way, including qualitative aspects and skills acquisition that is not related to formal education but rather to training and skill acquisition by experience, would as such already be very relevant for policy purposes. For that reason, this first component $(A)$ would be valuable even without the contiguous analyses of the relationship between skills shortages and productivity (B) and employment and unemployment (C).

On the other hand, the production function models mentioned restrict the analyses to the effects of the input of skills on productivity itself. The aim of this research programme, however, is also to relate skills shortages to effects on employment and unemployment. Therefore, an additional extension is needed in which these effects on employment and unemployment are included into the analysis. The diagram presented in Table 2 seems to be an appropriate point of departure for such analyses.

The proposed programme consists of three parts:

A. The monitoring of skills shortages

B. Skills shortages and productivity

C. Skills shortages, employment and unemployment

\section{A. The monitoring of skills shortages}

In the first place, before the impact of skills shortages can be analysed, more information on the existence of skills shortages in the EU must be generated. Chapter 2 contains a proposal for a set of five indicators. These indicators are:

- quantitative skills shortages;

- the quality of the skills;

- labour costs;

- perceived skills shortages;

- adjustment policies of firms.

To obtain an overview of existing skills shortages, data for this proposed set of indicators must be collected for different categories of skills in the countries of the EU. Since it is important to relate the performance of the EU to its main competitors, the inclusion of the United States and Japan in this Skills shortages Monitor will enhance the usefulness of the analyses. In addition, some of the specific instruments for the measurement of skills shortages, as described in Chapter 4 are based on econometric models. Although very useful for the study of skills shortages, these instruments have the disadvantage that the level of aggregation they allow for is rather limited. We suggest to limit phase $A$ of the research programme - the determination of skills shortages - to data sources that are directly available, leaving econometric analyses for phases $B$ and $C$. In this way, the research programme 
contains both parts in the trade-off between the direct use of survey data - which allows a high degree of detail and qualitative differentiation - and econometric analyses - in which theoretical consistency can be achieved and relationships can be investigated. Phase A concentrates on the collection of data for the set of indicators for skills shortages and the interpretation of these figures in a international comparative way, both among the various countries of the European Union and between EU Member States and other competing countries. Previous studies have shown that monitoring of relevant indicators within a consistent theoretical framework is in itself already very useful for a coherent view of the problem concerned (see e.g. De Grip et al., 1997). It will be difficult, however, to find data on all aspects of the set of indicators for all EU Member States. It must be decided therefore whether it is preferred to start with the collection of a restricted set of data on skills shortages for all EU Member States or to focus the analyses first on a few countries in the EU for which good data are available, or to follow a 'dual' strategy on this point. The use of existing data will leave open certain white spots, but experience has shown that the combination of different data sources generally leads to a sufficient body of evidence. Postponing the analyses until the ideal data are available leads to huge costs for the collecting of data, a considerable delay until the information becomes available and finally, a lack of learning in this respect may lead to initial results of a new survey that do not really meet the expectations. The construction of indicators on skills shortages on the basis of existing data generates the experience that may be used to supplement existing data with targeted additional surveys. These additional surveys will be less expensive and at the same time better suited for their job.

The quantitative skills shortages will be based on an international comparison of the percentages of workers who have the required skills. These available skills constitute the 'relative factor endowments' of the various countries. For this purpose, the European Labour Force Survey can be used although information on education is rather scarce in this survey. Other sources may therefore complement this aspect. Especially for some selected key qualifications, a search for more specific data could be worthwhile. Furthermore, these figures only provide an indication of the formal qualifications. A useful supplement to these figures can be found in data sources about on-the-job training in the countries investigated. The Continuing Vocational Training Survey in Enterprises 1994 (CVTS) of EUROSTAT may provide such information. The Luxembourg Employment Study (LES) also contains highly relevant information with respect to these topics for some selected European countries and the United States.

Information about the quality of the skills should be collected from surveys of employees or school-leavers in which questions are asked about the types of job they have and the way in which their skills match the jobs they have. Again, the Labour Force Survey can be used but more detailed information can probably be obtained from the household panels, such as the British Household Panel, the Dutch Socio-economic panel and the OSA panel of labour supply. Such household panels will be integrated in EUROSTAT's European Household Panel. The contents may 
vary between countries, however. Again it is not clear whether adequate data about these qualitative aspects is available for each EU Member State. An addition to this data on achievement scores as published by the OECD may complement the information on the quality of skills.

Information about labour costs can be deduced from surveys of employees or on wage structure surveys. The Lower network will publish a report on data sources on wages in the Member States of the EU. In addition to the data available at EUROSTAT, the Luxembourg Income Study may also provide useful information.

For data on perceived skills shortages, vacancy surveys seem to be most appropriate. Again these are so far not available for all European countries, although EUROSTAT investigated the possibility of a European vacancy survey. Muysken (1994b) provides information about the existing vacancy surveys in Europe, Canada and the United States. Furthermore, the Community Innovation Survey contains the question whether a shortage of qualified personnel is a bottleneck for the innovative activities of a firm.

Lastly, information about adjustment policies can be gathered from surveys of firms or employees. Again, the household surveys of EUROSTAT or the Member States will be relevant, while the Luxembourg Employment Study also provides useful information for the countries included.

\section{B. Skills shortages and productivity}

Complemented by data on the productivity of sectors of industry in the countries of the EU and some other western countries, a model can be developed in which the various aspects of skills shortages are linked to this productivity. In this model, a production function explains the effects of the input of certain categories of skills in a sector of industry on its output. Such an analysis provides insight in the contribution of different skills to productivity. The results of this model can therefore be used to analyse the effects of the availability of skills on economic output. The optimal economic output here determines the point of reference for the analysis of skills shortages. For each country, it can be estimated how great lost production as a result of skills shortages is, and what types of skill form the major bottleneck in this production process. As a consequence, this productivity analysis provides insight in the seriousness of the skills shortages concerned.

As mentioned at the beginning of this section, the existing models based on production functions only distinguish skills measured by formal qualifications. The results of these studies can be improved from the perspective of skills shortages if qualitative elements and indications for the different types of skills shortages are also included. The data collected in phase A can form the input for this. By including the possibility in the model that classes of skills in each country have different productivity levels, additional conclusions can be drawn concerning the effectiveness of the qualitative and quantitative skills measured by the set of indicators in phase $A$. 
The results of this econometric model can therefore be used to validate the findings of the first step concerning skills shortages.

\section{Skills shortages, employment and unemployment}

Lastly, the model developed in phase $B$ must be extended to analyse the implications for employment and unemployment. To this end, we must distinguish the four effects of skills. As indicated in Table 2, the worker effect seems to influence employment only in the case of classical skills shortages. The impact of this effect on unemployment can be tested by measuring the correlation between unemployment rates and the indicator for these skills shortages.

Figure 3

The three phases of the research programme for the analysis of the effect of skills shortages on economic development, employment and unemployment.

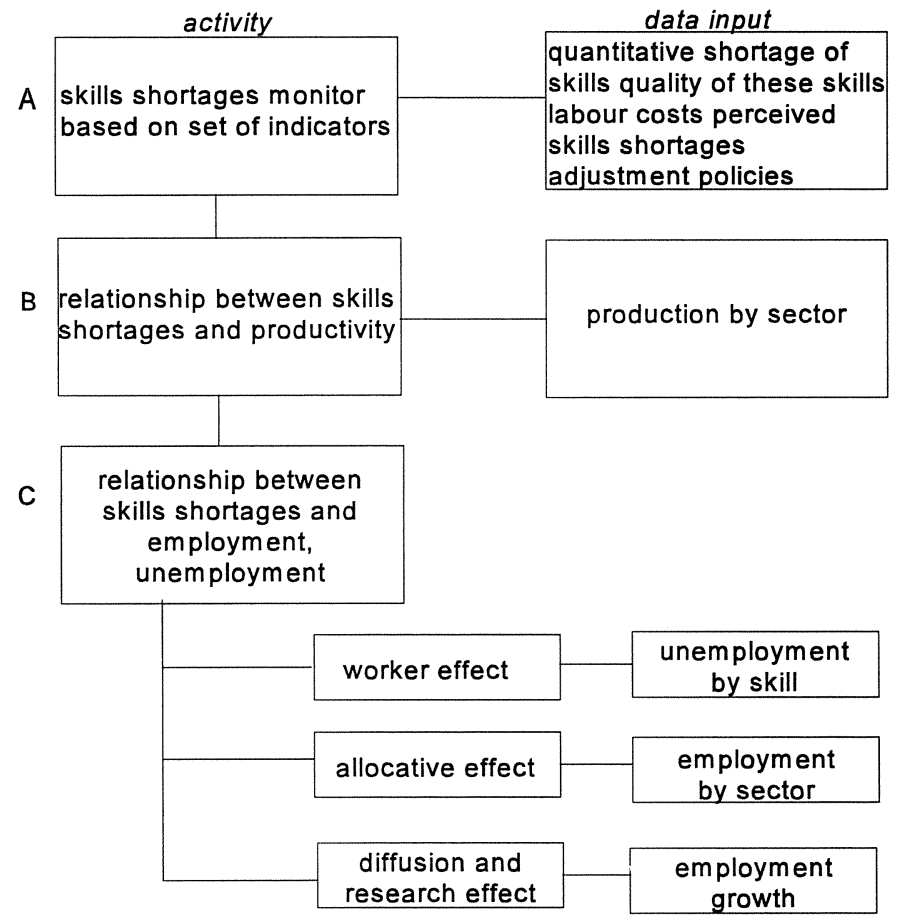

The allocative effect may hamper employment or productivity within a sector. The model that explains productivity at the sector level should therefore be extended with an analysis of the relation between skills shortages and employment. This relationship may be different for the three types of skills shortages distinguished. 
Finally, the diffusion effect and the research effect may not only reduce the level of productivity and employment, but also their growth. Cörvers (1994) showed that it is difficult to distinguish diffusion and research effects empirically. We therefore suggest to combine both effects and analyse the impact of the three types of skills shortages on the growth of production and employment. Figure 3 summarises the three phases of the research programme. 


\section{References}

Bartel, A.P. and F.R. Lichtenberg (1987), The comparative advantage of Educated Workers in Implementing New Technology, The Review of Economics and Statistics, vol. 69, pp. 1-11.

Bastianen, R.D. and J.C. van Ours (1990), Personeelsadvertenties in de jaren zeventig en tachtig, Economische Statistische Berichten, vol. 75, no. 3741, pp. 68-70.

Bean, C.R. and C.A. Pissarides (1991), Skill shortages and Structural Unemployment in Britain: A (Mis)matching Approach, in F. Padoa-Schioppa (ed.), Mismatch and Labor Productivity, Cambridge University Press, Cambridge, pp. 325-353.

Borghans, L. (1992), A Histo-Topograpic Map of the Dutch University Studies, Research Centre for Education and the Labour Market, ROA-W-1992/5E, Maastricht, The Netherlands.

Borghans, L. (1993), Educational Choice and Labour Market Information, thesis, Maastricht.

Borghans, L., G. Hughes and W. Smits (1997), The Occupational Structure of Higher Education in Ireland and the Netherlands, Cedefop, Brussels.

Bosworth, D., and P. Duton and J. Lewis (eds.) (1992), Skill shortages: Causes and Consequences, Avebury, Aldershot.

Bosworth, D. and P. Warren (1992), Modelling skill shortages, in Bosworth, D., P. Duton and J. Lewis, (eds.), Skill shortages: Causes and Consequences, Avebury, Aldershot, pp. 24-48.

Brusten G., P. de Coninck and B. van Schel (1994), Measurement and analysis of vacancies in Flanders, in J. Muysken (ed.) Measurement and Analysis of Job Vacancies, Avebury, Aldershot, pp. 55-78.

Burdett, K. and E. Cunningham (1994), The duration of a vacancy, in J. Muysken (ed.), Measurement and Analysis of Job Vacancies, Avebury, Aldershot, pp. 147-168.

CBI (1987), Confederation of British Industry/Manpower Services Commission, Special Survey of Skills shortages.

Cohen, M.S. (1995), Labor Shortages as America Approaches the Twenty-first Century, The University of Michigan Press.

Cörvers, F. (1994), Human Capital Factors at the Firm Level, Research Centre for Education and the Labour Market, ROA-W-1994/7E, Maastricht, The Netherlands.

Cörvers, F., A. de Grip and J.P. Orbon (1995), Concurrentiekracht, produktiviteit en human capital: een vergelijking tussen Nederland en Duitsland, Research Centre for Education and the Labour Market, ROA-RM-1995/2, Maastricht, The Netherlands.

Cörvers, F. and A. de Grip (1997), Explaining Trade in Industrialized Countries by CountrySpecific Human Capital Endowments, Economic Modelling, vol. 14, pp. 395-416.

Cörvers, F. (1997), The impact of human capital on labour productivity in manufacturing sectors of the European Union, Applied Economics, vol. 29, pp. 975-987.

Daley, A. (1996), Education and Productivity: A comparison of Great Britain and the United States, British Journal of Industrial Relations, vol. 24, pp. 251-266.

Davies, S. and R.E. Caves, (1987), Britain's productivity gap, Cambridge University Press, Cambridge.

De Grip, A. , M. van Smoorenburg, L. Borghans and N. Jonker (1997), Werkgelegenheid en scholing 1996, Research Centre for Education and the Labour Market, ROA-R-1997/1, Maastricht.

European Commission (1996), Teaching and learning. Towards the learning society, White Paper, Brussels.

Frey, K. (1982), Curriculum conference: An approach for curriculum development in groups, 
Institute for Science Education, Kiel.

Green F. and D. Ashton (1992), Skill shortages and Skill Deficiency: A Critique, Work, Employment and Society, vol. 6, pp. 287-301.

Grossman G.M. and Helpman E. (1992), Innovations and Growth in the Global Economy, MIT Press, Cambridge MA.

Holzer, H.J. (1994), Job Vacancy Rates in the Firm: An Empirical Analysis, Economica, vol. 61, pp. 17-36.

Kern, H. and M. Schumann, (1990), Das Ende der Arbeitsteilung? Rationalisierung in der industriellen Produktion, Verlag C.H. Beck.

Killingsworth, M.R. (1982), 'Learning by Doing' and 'Investment in Training': A Synthesis of two 'Rival' Models of the Life Cycle, Review of Economic Studies, XLIV, pp. 263-271.

Kunst, P., J. Lemmink and R. Prins (1996), Interrelationships between key parameters of service quality. A study to explore best practices in the service sector in EU Member States, MERIT, Maastricht.

Liff, S. (1992), Patterns of innovation and skills shortages, in: D. Bosworth, P. Duton and J. Lewis (eds.), Skills shortages: Causes and Consequences, Avebury, Aldershot, pp. 81-90.

Marsden, D. and P. Ryan, (1991), Initial Training, Labour Market Structure and Public Policy: Intermediate Skills in British and German Industry, in P. Ryan (ed.) International Comparisons of Vocational Education and Training for Intermediate Skills, The Falmer Press, pp. 251-285

Mulder, M. (1992), The curriculum conference: Evaluation of a tool for curriculum content justification, Faculteit der Toegepaste Onderwijskunde, Universiteit Twente, Enschede.

Muysken, J. H. Bierings and E. de Regt (1994), Vacancy data, the employment function and structural unemployment in the Netherlands, in J. Muysken (ed.), Measurement and Analysis of Job Vacancies, Avebury, Aldershot, pp. 259-289.

Muysken, J. (ed.) (1994a), Measurement and Analysis of Job vacancies: an International Comparison, Avebury, Aldershot.

Muysken, J. (1994b), Introduction, in J. Muysken (ed.), Measurement and Analysis of Job Vacancies: an international comparison, Avebury, Aldershot, pp. 1-11.

Nelson, R.R. and Phelps, E.S. (1966), Investment in Humans, Technological Diffusion and Economic Growth, American Economic Review Papers and Proceeding, vol. 56, pp. 69-75.

Nijhof, W.J. (1996), Curriculumkenmerken en arbeidsmarktperspectieven, Universiteit Twente, Enschede.

OECD (1996a), Education at a glance. OECD Indicators, OECD, Paris.

OECD (1996b), Measuring What People Know. Human Capital Accounting for the Knowledge Economy, OECD, France.

Oosterhuis, J.A.J.J. and R.K.W. van der Velden (1994), Skills shortages in the 90s, ROA-R1994/8E, Maastricht.

Praat, W.C.M., H.R.M. Smulders and J.W. van Werkhooven, (1996), Trendrapport vraag naar arbeid 1996, Organisatie voor Strategisch Arbeidsmarktonderzoek, OSA report 22.

Psacharipoulos, G., (1981), Returns to education: an updated international comparison, Comparative education, vol. 17, pp. 321-341.

Ram, R. (1980), Role of Education in Production: A Slightly New Approach, Quarterly Journal of Economics, vol. 94, pp. 365-373.

Romer, P.M. (1990), Endogenous Technological Change, Journal of Political Economy, vol. 98, s71-s102. 
Ryan, P. (ed.) (1991), International Comparisons of Vocational Education and Training for Intermediate Skills, The Falmer Press, London.

Schettkat, R. (1994), On vacancies in Germany, Jahrbuch für Nationalök. und Stat., G. Fisher Verlag, Stuttgart.

Senker, (1992), Skill shortages and Britain's international competitiveness, in: D. Bosworth, P. Dutton and J. Lewis (eds.) Skill shortages: causes and consequences, Avebury, Aldershot, pp. 10-23.

Sneessens, H.R. (1995), Courbe de Beveridge et demande de qualifications, Économie et Prévision, 113-114, pp. 127-138.

Sneessens, H.R., Asymmetric Growth Effects, Skill Mismatch and Unemployment Persistence, OECD, Paris.

Steedman, H. (1987), Vocational Training in France and Britain: office work, National Institute Economic Review, May, pp. 58-70.

Steedman, H. and K. Wagner (1987), A second look at productivity, machinery and skills in Britain and Germany, National Institute Economic Review, November, pp. 84-97.

Teulings, C.N., (1995), On vacancies, TI- 95-146, Tinbergen Institute, University of Amsterdam, Amsterdam.

Trutko, J.W., B.S. Barnow, A.B. Chasanov and A. Pande (1991), Labor Shortage Case Studies, Washington D.C., Employment and Training Administration, U.S. Department of Labor.

Van Bastelaer, A., J. Laan (1994), The Job Vacancy Survey in the Netherlands, in J. Muysken (ed.), Measurement and Analysis of Job Vacancies, Avebury, Aldershot, pp. 13-31.

Van Dam, J.W. van and R.K.W. van der Velden (1991), New technologies, skills shortages and training policy: a comparative approach between branches of industry, Research Centre for Education and the Labour Market,ROA-W-1991/3E, Maastricht.

Van de Loo, P.J.E. , J. Hoevenberg and R.K.W. van der Velden (1995), De arbeidsmarktpositie van afgestudeerden van het hoger Onderwijs, HBO-monitor 1994, HBO-Raad, The Hague.

Van Smoorenburg, M.S.M. and R.K.W. van der Velden (1995), Schoolverlaters op de arbeidsmarkt, De uitstroom en bestemming van het schooljaar 1992-1993, Landelijk Dienstverlenend Centrum voor Studie- en beroepskeuzevoorlichting, Leeuwarden.

Webster, J. (1990), Office automation: The Labour Process and Women's work in Britain, Harvester Wheatsheaf, Brighton.

Welch, F. (1970), Education in production, Journal of Political Economy, vol. 78, pp. 35-59.

Wilkinson, B. (1983), The Shopfloor Politics of new Technology, Heinneman, London.

Wood, A. (1995), North-South Trade, Employment and Inequality, IDS Development Studies Series, Clarendon Press, Oxford. 
